\title{
Resource curse or not: A question of appropriability*
}

\author{
Anne D. Boschini \\ Stockholm University
}

\author{
Jan Pettersson \\ Stockholm University
}

\author{
Jesper Roine \\ Stockholm School of Economics
}

September 18, 2003

SSE/EFI Working Paper Series in Economics and Finance, No 534

\begin{abstract}
This paper shows that whether natural resources are good or bad for a country's development depends crucially on the interaction between institutional setting and the type of resources that the country possesses. Some natural resources are for economical and technical reasons more likely to cause problems such as rent-seeking and conflicts than others (termed technically appropriable resources). This potential problem can, however, be countered by good institutional quality (rendering these resources less institutionally appropriable). In contrast to the traditional resource curse hypothesis we show that the impact of natural resources on economic growth is non-monotonic in institutional quality. Mineral rich countries are cursed only if they have low quality institutions, while the curse is reversed if institutions are good enough. Using new data we find that this is even more stark for countries rich in diamonds and precious metals.
\end{abstract}

Keywords: natural resources, appropriability, property rights, institutions, economic growth, development

JEL: O40, O57, P16, O13, N50

${ }^{*}$ The authors wish to thank Oriana Bandiera, Per Pettersson, Silvia Pezzini, Peter Skogman Thoursie and Fabrizio Zilibotti for insightful discussions and comments. Corresponding author: Anne Boschini, Department of Economics, Stockholm University, 10691 Stockholm, Sweden. Email: anne.boschini@ne.su.se 


\section{Introduction}

A major puzzle in the pattern of economic development across countries over the past decades is the apparently negative relationship between economic growth and large natural resources. Observers of recent successes and failures have noted that while some of the fastest growing economies during this period have been countries with very little natural wealth (such as Hong Kong, Singapore, Korea, and Taiwan), some of the poorest economic performers (like Angola, Sierra Leone, and Zaire) are countries with enormous resources. A number of recent studies has concluded that this negative association between resource abundance and growth also holds for large samples of countries even when controlling for other relevant characteristics. ${ }^{1}$ This relationship, the so called 'resource curse', has become "widely accepted as one of the stylized facts of our times". ${ }^{2}$

However, there are many countries whose experiences show that the resource curse is not inevitable. While a country like Sierra Leone seems to have been hurt by having diamonds, Botswana - one of the world's fastest growing economies over the past thirty years - has an economy completely dominated by the same resource. In Venezuela, oil appears to have been the cause of recurrent problems. Norway, on the other hand, has become one of the world's richest economies owing much to its oil endowments. There are several examples of countries rich in similar resources with comparable shares of natural resource exports in GDP - that have experienced extremely different economic growth. Looking at the examples in Table 1, it seems that for every catastrophic failure there is a counter example of success.

In this paper, by using new data on natural resources, we show that resource abundance in itself is not negative for a country's economy. What matters is what we call the appropriability of the resource, that is how easy it is to realize large economic gains, within a relatively short period of time, from having control over it. The appropriability of a resource depends on two things. The physical and

\footnotetext{
${ }^{1}$ E.g. Sachs and Warner (1995), Gylfason, Herbertson and Zoega (1999) and Leite and Weidemann (1999). Ross (1999) provides an overview of much of this literature.

${ }^{2}$ Wright (2001), p. 1.
} 
economical characteristics of the resource - it's technical appropriability - as well as the legal and political context in which the resource is produced - it's institutional appropriability.

\begin{tabular}{lcccc}
\hline \hline & $\begin{array}{c}\text { Growth } \\
\mathbf{1 9 7 5 - 1 9 9 8}\end{array}$ & $\begin{array}{c}\text { Main } \\
\text { resource* }\end{array}$ & $\begin{array}{c}\text { Institutional } \\
\text { quality** }\end{array}$ & $\begin{array}{c}\text { Share of primary } \\
\text { exports in GDP*** }\end{array}$ \\
\hline Botswana & 4.99 & Diamonds & 0.706 & 0.05 \\
Chile & 3.71 & Copper & 0.668 & 0.15 \\
Norway & 2.82 & Crude Petrol & 0.966 & 0.10 \\
Canada & 1.73 & Minerals & 0.974 & 0.10 \\
Average & 1.53 & n.a. & 0.638 & 0.12 \\
Venezuela & -0.79 & Crude Petrol & 0.592 & 0.24 \\
Niger & -1.45 & Minerals & 0.520 & 0.05 \\
Sierra Leone & -2.05 & Diamonds & 0.406 & 0.09 \\
Congo, Dem. Rep. & -5.39 & Copper & 0.232 & 0.15 \\
& & & & \\
\hline \hline
\end{tabular}

\footnotetext{
*The listing of main resources is based on UNCTAD data on export structure in 1975. **The measure of institutional quality is a "Property Rights Index" based on data from Keefer and Knack (2002). The index score for a country is between zero and one where higher scores mean better institutional quality. See Appendix A for details.

***The share of primary exports in GDP in 1971 is from Sachs and Warner (1995).
}

Table 1. Relative growth performance in eight resource rich economies

The concept of technical appropriability is introduced to capture the idea that certain types of natural resources are, ceteris paribus, more likely to cause appropriative behavior. Resources which are very valuable, which can be stored, which are easy to transport (or smuggle), and which are easily sold are, for obvious reasons, more attractive for anyone interested in short-term illegitimate gains. This suggests that as a potential source of conflict or rent-seeking, resources such as diamonds are more problematic than, say, wheat. ${ }^{3}$

However, this does not mean that all countries with diamonds are doomed, while

\footnotetext{
${ }^{3}$ Indeed, many of the previous case studies of development failure and resource abundance are concerned with mineral rich countries, rather than countries rich in natural resources in general. "Blood Diamonds: Tracing the Deadly Path of the World's Most Precious Stones" by Greg Campbell (2002), deals with conflict diamonds, Terry Lynn Karl's (1997) recent work "The Paradox of Plenty: Oil booms and Petro States", gives examples of problems related to oil, and "Sustaining Development in Mineral Rich Economies", by Richard Auty (1993), studies countries dependent on non-ferrous metals.
} 
those with wheat will do fine. The potential problem of having technically appropriable resources can be countered by good institutions, implying that the impact of resource abundance on economic performance is predicted to be non-monotonic in institutional quality. Resources such as diamonds, precious metals or oil are expected to be negative for economic performance only in countries where measures of institutional quality are low, while they will have a positive impact on the economy in countries with good institutions. As resources become less technically appropriable, the relative importance of institutions is predicted to be less decisive.

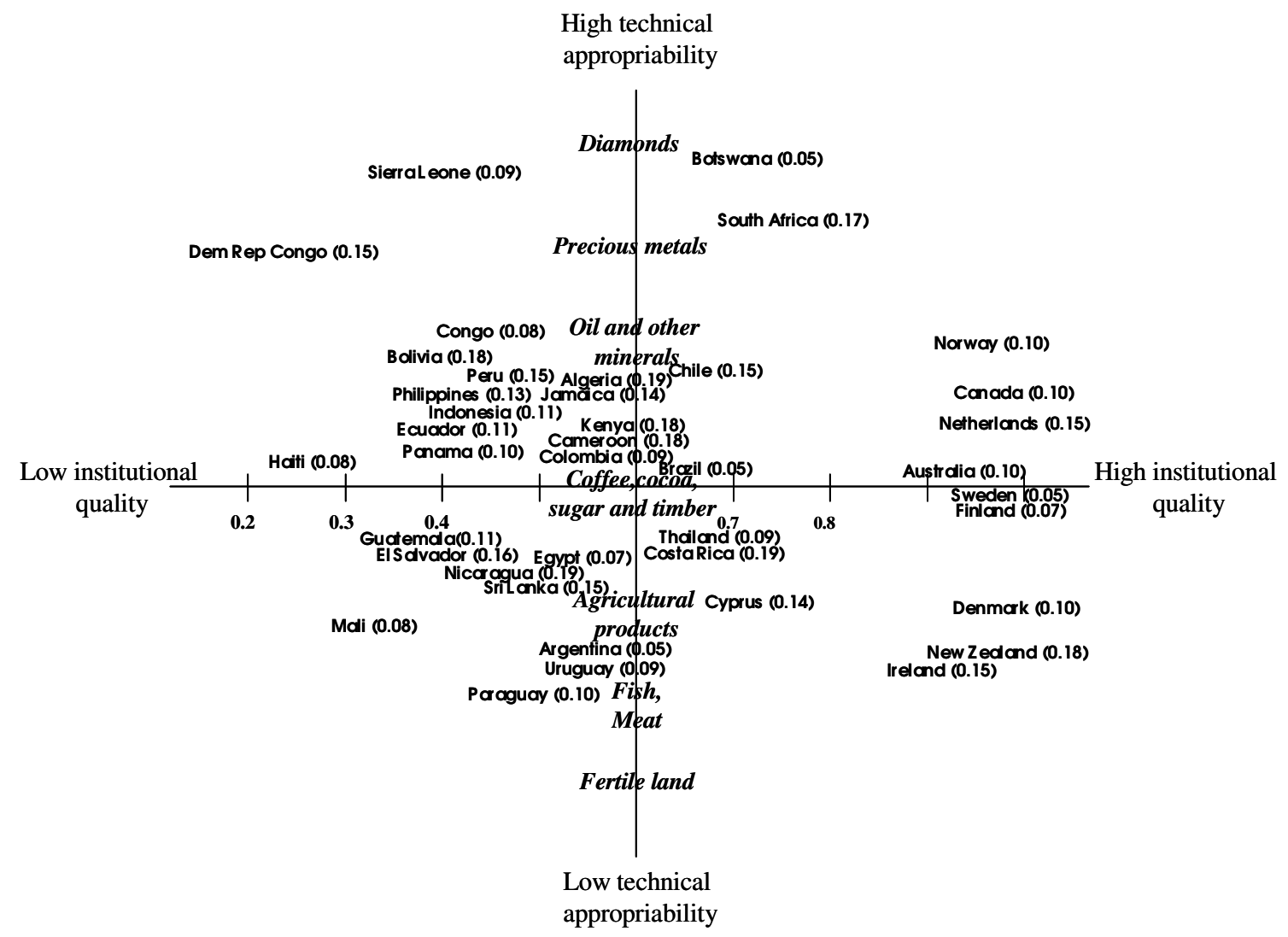

Figure 1. The two dimensions of resource appropriability. (The number adjecent to each country name is the share of primary exports in GDP in 1971)

Plotting countries with respect to the two dimensions of resource appropriability can serve as a simple illustration of our theory. Figure 1 shows a number of countries with similar shares of primary exports in GDP (a common proxy for natural 
resources) graphed with respect to type of resource and institutional quality. ${ }^{4}$ In the first and fourth quadrant are countries with technically appropriable resources. ${ }^{5}$ Those to the left of the $\mathrm{y}$-axis have lower than average measures of institutional quality, while those to the right have better than average institutions. ${ }^{6}$ According to any theory which emphasises the share of primary exports as important for economic performance, these countries should roughly do equally well.

Our prediction is that countries in the first quadrant will benefit from their natural wealth, while countries in the fourth quadrant will instead be "cursed" by their endowments. For countries in the second and third quadrant - countries with less technically appropriable resources - the effects from the interaction between natural resources and institutions are less instrumental for economic development.

In the following sections we will develop our hypothesis in greater detail and test it empirically. Section 2 relates this paper to the previous writings on the effects of resource abundance on economic development. In Section 3, we specify our hypothesis and present our data. In particular, we report how we have constructed our measure for the most appropriable resources. Section 4 tests our hypothesis using LS regressions of GDP growth on different measures of natural resources, institutions and their interactions. We also address the issue of endogenous institutions and run 2SLS regressions instrumenting for institutional quality. In Section 5 we check the

\footnotetext{
${ }^{4}$ The included countries are all those in our data set with shares of primary export in GDP between 0.05 and 0.20 . The average value for the respective quadrants is 0.11 for the first, 0.14 for the second, 0.11 for the third and 0.13 for the fourth quadrant. This means that in terms of this proxy for natural resource wealth the countries in the respective quadrants are, on average, very similar.

${ }^{5}$ Countries are classified according to their three leading primary exports in 1975 . The lead export is the main determinant of the countries position in the graph and the second and third most important primary product determines the "direction" in which the country is placed. In Brazil and in Thailand, for example, sugar is the lead export. But in Brazil the second and third exports are coffee and iron ore, in Thailand they are rice and maize, so Brazil is moved up toward minerals relative to the heading "coffee, cocoa, sugar and timber", while Thailand is moved down toward agriculture products. Some countries, such as Australia, are dominated by relatively equal shares of minerals and agricultural product and are therefore positioned in between these labels. Exactly how to rank natural resources in terms of technical appropriability is, of course, debatable. We will, in our analysis, only distinguish between a broad measure of natural resources (which include all primary products) and narrower measures of more appropriable resources which includes only ores and metals, and an even narrower measure of what we define as the most appropriable resources including only precious metals and diamonds. See Auty (1997) and Woolcock, Pritchett and Isham (2001) for a slightly different distinction between types of resources.

${ }^{6}$ Institutional quality is measured as an (unweighted) average of indexes for the quality of the bureaucracy, corruption in government, rule of law, the risk of expropriation of private investment and repudiation of contracts by government. See Appendix A for details.
} 
robustness of our results with respect to influential observations, sample size, and choice of institutional variable. Section 6 concludes.

\section{Related literature}

There is strong evidence that resource abundant countries have had lower average growth rates in the Post-war period compared to their resource-poor counterparts. However, there seems to be little agreement on why this relationship exists. The different theories that have been advanced can usefully be grouped into economic and political-economy explanations. ${ }^{7}$

Most of the recent economic explanations are versions of the so called "Dutch Disease". 8 The basic argument in these models is that windfall gains from natural resources (either through sudden increases in the price of the resource, or through the discovery of new resources) have a crowding-out effect on other sectors of the economy. For example, in Sachs and Warner (1995), following Matsuyama (1992), positive externalities in the form of learning-by-doing are assumed to be present only in the manufacturing sector of the economy. This implies that the larger is the natural resource sector (and the smaller is the manufacturing sector), the smaller is the positive externality that feeds the growth process. These theories do not seem to explain all the facts of the data..$^{9}$ Most importantly, all of these explanations predict a monotonic negative effect of resources. The more natural wealth, the worse the outcome. As such, these theories cannot explain why Botswana and Norway have been successful, while Sierra Leone and Venezuela have not.

\footnotetext{
${ }^{7}$ One could, of course, add "pure" political explanations, such as the "rentier effects" and (anti) "modernization effects" (see Ross (2001) for a discussion of these) as well as sociological studies of negative effects of resources on development (see Ross (1999), footnote 2).

${ }^{8}$ For example, Corden and Neary (1982), Neary and van Wijnbergen (1986) and Krugman (1987). For other economic theories based on , for example, declines in terms-of-trade and sensitivity to volatile commodity prices, see the overview in Ross (1999).

${ }^{9}$ In Gelb (1988) several studies find that the mechanisms suggested by these models were not there in the data. Resource booms have not shifted capital and labor away from manufacturing. Furthermore governments seemed to be able to counter the "disease" if necessary. As concluded by Neary and van Wijnbergen (1986): "In so far as one general conclusion can be drawn it is that a country's economic performance following a resource boom depends to a considerable extent on the policies followed by its government...".
} 
A number of papers has put forward more politico-economic explanations for why natural resources have negative effects on growth. Lane and Tornell (1999) and Torvik (2002) have developed theoretical models of rent-seeking where resource abundance increase the incentives to engage in "non-productive" activities to capture the rents from the resources. Even though these papers certainly give important insights, they also predict a monotone adverse effect of natural resources on economic growth. Collier and Hoeffler (1998) and (2002) point to resources as a source of armed conflict. They find a non-linear relationship between natural resources and the risk of armed conflicts, but they still do not explain why some resource rich countries prosper whereas others fail.

Engerman and Sokoloff (2002) develop a theory of the diverging growth paths of North and South America according to which the types of resource endowments explain the evolution of institutions and the following economic development. Put, simply, some countries enjoyed conditions favorable for growing crops, such as sugar, which were most efficiently produced on large plantations. This led to concentrations of wealth, political power, and human capital, and in the long run to worse economic outcomes. In similar spirit, Acemoglu, Johnson and Robinson (2001) argue that initial conditions (specifically, settler mortality rates) influenced the institutional development, which in the long run has come to produce different economic outcomes.

Relating to these articles, some have argued that, once institutions are controlled for, there is no separate effect from "geographical" factors - for example, Easterly and Levine (2002) and Rodrik, Subramanian and Trebbi (2002). However, "geography" or "initial factor endowments" are not necessarily the same thing as resource abundance today (or in the past decades). It is true that "geography is as exogenous a determinant as an economist can ever hope to get" (Rodrik et al. (2002), p. 2) if one by this means factors such as distance from equator, tropical climate, or factor endowment at the time of early settlements, and it is also likely that these factors had a major role in shaping the institutions of various countries. But, this does 
not necessarily mean that the natural resources which are most important today played any part in this development. For example, it seems unlikely that oil would have given rise to good institutions in Norway and bad ones in Venezuela, or that diamonds have helped form good institutions in Botswana and bad ones in Sierra Leone. It seems more plausible that the very different impact that these discoveries has had on the development in these countries can be understood by their institutional differences.

Auty (1997), Woolcock, Pritchett and Isham (2001), and Isham, Woolcock, Pritchett and Busby (2003) have - as we do in this paper - stressed the importance of the types of resources. So called "point source" resources, such as plantation crops, oil and diamonds, are more likely to cause problems than "diffuse" natural resources, such as rice, wheat and animals. These theories provide predictions on why different resource rich countries may be affected differently by their natural wealth. Those with plantation crops, oil or diamonds are more likely to have bad outcomes than those with rice, wheat and animals. This prediction seems to be supported by data, however, these theories can still not account for the facts in Table 1. Why is it that when comparing countries with similar natural resources, some seem to gain from their endowments when others lose?

We propose an explanation to why the effects of natural resources on growth can be different between countries with similar resources. The reason we suggest is that the relationship between natural resources and growth is non-monotonic in institutional quality. In general, our prediction is that countries with good institutions will not suffer a resource curse while those with bad institutions will. Relating to the theories of resources as a source of rent-seeking of conflict, the idea is that better institutions increase the costs of non-productive activities. ${ }^{10}$ Merging these with theories suggesting that types of resources matter, we also claim that the nonmonotonicity will depend on what resources the country is rich in. Those endowed with resources, which due to their technical nature are more likely to cause prob-

\footnotetext{
${ }^{10}$ This idea echoes Rodrik (1999), who stresses the role of institutions of conflict management.
} 
lems, have more to gain from better institutions as well as more to lose from bad ones, than do those endowed with less technically appropriable natural resources. Because of this, institutional quality is most crucial for countries rich in diamonds and precious metals. Such countries, which have poor institutions, are expected to have the largest negative effects from resources, while similar countries with good institutions are predicted to have large gains from them.

The two papers most closely related to ours are Mehlum, Moene and Torvik (2002) and Robinson, Torvik and Verdier (2002). These papers share our prediction of the effect of resources being non-monotonic in institutional quality. They do not, however, distinguish between different types of resources and, perhaps more importantly, they are both mainly theoretical papers.

\section{Our hypothesis and data}

In contrast to the standard resource curse, our basic hypothesis is the following. Natural resource abundance is negative for economic development only if the country lacks the proper institutions to deal with the potential conflicts and the rent-seeking behavior that the resources otherwise may result in. A lack of proper institutions is likely to be more serious for countries rich in technically appropriable resources. This can be stated as two separate hypothesis.

Institutional appropriability hypothesis: Natural resource abundance is negative for economic development only under poor institutions.

Technical appropriability hypothesis: The impact of institutional quality and abundant natural resources is more pronounced the more technically appropriable are the country's natural resources.

The basic econometric specification for testing the proposed effects of resources and institutions in country $i$ becomes

$$
\text { growth }_{i}=X_{i}^{\prime} \alpha+\beta_{1} N R_{i}+\beta_{2} \text { Inst }_{i}+\beta_{3}\left(N R_{i} \times \text { Inst }_{i}\right)+\varepsilon_{i},
$$


where growth is the average yearly growth rate of GDP, $X$ is a vector of controls including initial GDP per capita level, period averages of openness and investment ratios, dummy variables for Subsaharan Africa and Latin America respectively and a constant. $N R$ is a measure of natural resource wealth (for which we will use our four measures discussed below) and Inst is our measure of institutional quality. $N R \times$ Inst is the interaction between natural resources and institutional quality.

According to our first hypothesis $\beta_{1}$ should be negative (the standard resource curse finding), $\beta_{2}$ should be positive (the standard finding that good institutional quality is beneficial for growth) and $\beta_{3}$, the coefficient for the interaction between natural resources should be positive and - if it is to reverse the resource curse - have an absolute value larger than $\beta_{1}{ }^{11}$ This would mean that as long as the institutional quality is good enough, natural resources have a positive net effect on economic growth. Furthermore, our second hypothesis implies that the impact on the growth rate of GDP of both the negative effect of the resources themselves $\left(\beta_{1}\right)$ as well as the interaction with institutional quality $\left(\beta_{3}\right)$ should be stronger the more appropriable are resources and the weaker are institutions. Put differently, for countries rich in technically appropriable resources the institutional quality is more important than for others.

To be able to address our second hypothesis, we are limited by the availability of data for all natural resource measures for each country. This leaves us with a sample of 80 countries, both industrialised and developing (see Appendix A for a complete listing). Our dependent variable, growth, is defined as the average yearly growth rate of GDP between 1975 and 1998.

We use four different measures of natural resources to capture a gradual increase in technical appropriability. As the broadest measure we use Sachs and Warner's (1995) share of primary exports to GNP, PrimExp (by them labelled $S X P$ ). In terms of appropriability this measure includes everything from meat to precious metals, that is the whole range of the $y$-axis in Figure 1. Second broadest is OrMetExp,

\footnotetext{
${ }^{11}$ The fact that our measure of institutional quality has been rescaled to a 0-1 measure allows us to compare the coefficients directly.
} 
which includes the exports of ores and metals as a share of GDP - this corresponds to the upper half of the $y$-axis. A similar measure in terms of appropriability is MinProd, the share of mineral production in GNP. ${ }^{12}$ It differs, however, in two regards. It does not include ores and it is a production - not an export - measure. If technically appropriable resources are likely to be diverted on their way from production to export, this proxy is expected to contain less measurement error.

Our fourth and narrowest, measure MidasProd is the value of production of gold, silver, and diamonds (industrial as well as gem stone) as share of GDP - that is the very top of the $y$-axis in Figure 1. This measure is based on a combination of production and price data. Production data are from the U.S. Bureau of Mines, where production is reported in volumes. For price data on silver and gold, we employ average yearly market prices reported by the U.S. Geological Survey. Such prices do not exist for diamonds because of the large variation in quality. What we do have is the U.S. import quantities and values of diamonds (industrial and gem stone) from different countries. We use these to obtain the per carat price for each country, which we multiply with production data. The total value of gold, silver and diamonds for each country are divided by GDP to obtain MidasProd.

To lower the risk of reverse causality we use initial year measures for all four resource proxies. ${ }^{13}$ To capture institutional quality we employ the (unweighted) average of indexes for the quality of the bureaucracy, corruption in government, rule of law, the risk of expropriation of private investment and repudiation of contracts by government from Knack and Keefer (2002). Our control variables are the level of GDP per capita in 1975, investment and trade openness. ${ }^{14}$ (Sources and exact definitions of all variables are presented in Appendix A.) Table 3 reports the correlations between these main variables and addresses a number of issues. First, it

\footnotetext{
${ }^{12}$ This measure is also taken from Sachs and Warner (1995), where it is called $S N R$.

${ }^{13}$ The exception is MidasProd. Due to heavy volatility in prices during the years surrounding 1975 , we use the average of $1972,1974,1976,1978$ and 1980, in order to avoid the choice of a specific start year to influence our results. Our findings are however similar when using MidasProd for 1974 or 1976 .

${ }^{14}$ One control variable we have excluded is average years of schooling in the population, since it is highly correlated with the other control variables. The regression results are, however, robust to the inclusion of schooling.
} 
indicates that the measures of natural resources by themselves are not proxies for a country's level of development. In fact, the correlation between per capita GDP in 1975 and the different measures of natural resources is fairly low.

\begin{tabular}{|c|c|c|c|c|c|c|c|c|}
\hline & Growth & Institutions & PrimExp & DrMetExp & MinProd & MidasProd & Gdp75 & Open \\
\hline Institutions & 0.39* & & & & & & & \\
\hline PrimExp & $-0.34 *$ & $-0.29 *$ & & & & & & \\
\hline OrMetExp & -0.14 & -0.12 & $0.47 *$ & & & & & \\
\hline MinProd & $-0.45 *$ & $-0.33^{*}$ & $0.40 *$ & $0.42 *$ & & & & \\
\hline MidasProd & -0.03 & -0.07 & -0.02 & $0.31 *$ & $0.30 *$ & & & \\
\hline Gdp75 & 0.19 & $0.83 *$ & $-0.31 *$ & -0.17 & -0.22 & -0.14 & & \\
\hline Open & 0.23 & 0.17 & $0.30 *$ & 0.30 & -0.01 & 0.03 & 0.08 & \\
\hline Investment & $0.55^{*}$ & $0.73 *$ & $-0.31 *$ & -0.11 & $-0.31 *$ & -0.15 & $0.69 *$ & $0.30 *$ \\
\hline
\end{tabular}

Table 3. Correlation matrix for the entire sample

Moreover, this potential problem seems to be largest for the broadest measure of natural resources (PrimExp), while the narrower measures are not significantly correlated with the GDP level.

Second, in Table 3 institutions do not appear to be determined by natural resources in general nor does institutional quality seem to impact on the production of natural resources. In fact, all measures of natural resources are only modestly (negatively) correlated with institutions. ${ }^{15}$

Third, as evident from Table 3, some controls, especially initial GDP level and investment, are highly correlated with institutions. In order to check to what extent these correlations influence our conclusions, we use a more parsimonious empirical specification dropping and adding control variables. These results are presented in Appendix B for the use of MidasProd. ${ }^{16}$

\footnotetext{
${ }^{15}$ It is important to remember that our hypothesis is not that resources do not have an effect on the institutional setting in the very long run, only that the resources causing the "resource curse" have not driven the institutional development so far.

${ }^{16}$ One specification also includes schooling (see footnote 13). The use of other measures of natural resources yield the same changes and are available from the authors upon request.
} 


\section{Main results}

To test our hypotheses, we first run regressions using the broadest measure of natural resources (PrimExp). We then use our gradually narrower definitions of natural resources, letting the measure of resources include fewer, but more technically appropriable resources. If it is correct that more appropriable resources are more positive for economic development when institutional quality is good, but also increasingly problematic when institutions are bad, this should show in the impact of the coefficients on growth. As the measure of natural resources narrows down toward more technically appropriable resources, we expect the (negative) effect from resources $\left(\beta_{1}\right)$ as well as the (positive) effect from the interaction term $\left(\beta_{3}\right)$ to be more pronounced.

Columns (1)-(4) in Table 4 show our main results. In the first column we use the broadest measure of natural resources (PrimExp). Even though the signs of our three regressors of interest are in line with our first hypothesis, resources and the interaction are not significant. ${ }^{17}$ All control variables are significant and have the expected signs.

We then narrow down the measure towards more technically appropriable resources, reported in columns (2)-(4) in Table 4. Now, natural resources, institutions, and their interaction are all significant at the one per cent level (as well as jointly significant). The interaction effect outweighs the impact of the resources and hence for good enough quality of institutions resources tend to be positive for growth.

\footnotetext{
${ }^{17}$ This equation is fairly similar to the one presented in a parallel paper by Mehlum et al (2002). However, they use different data, a slightly different specification, and look at the period 1965-1990 which can explain the differences in our results.
} 


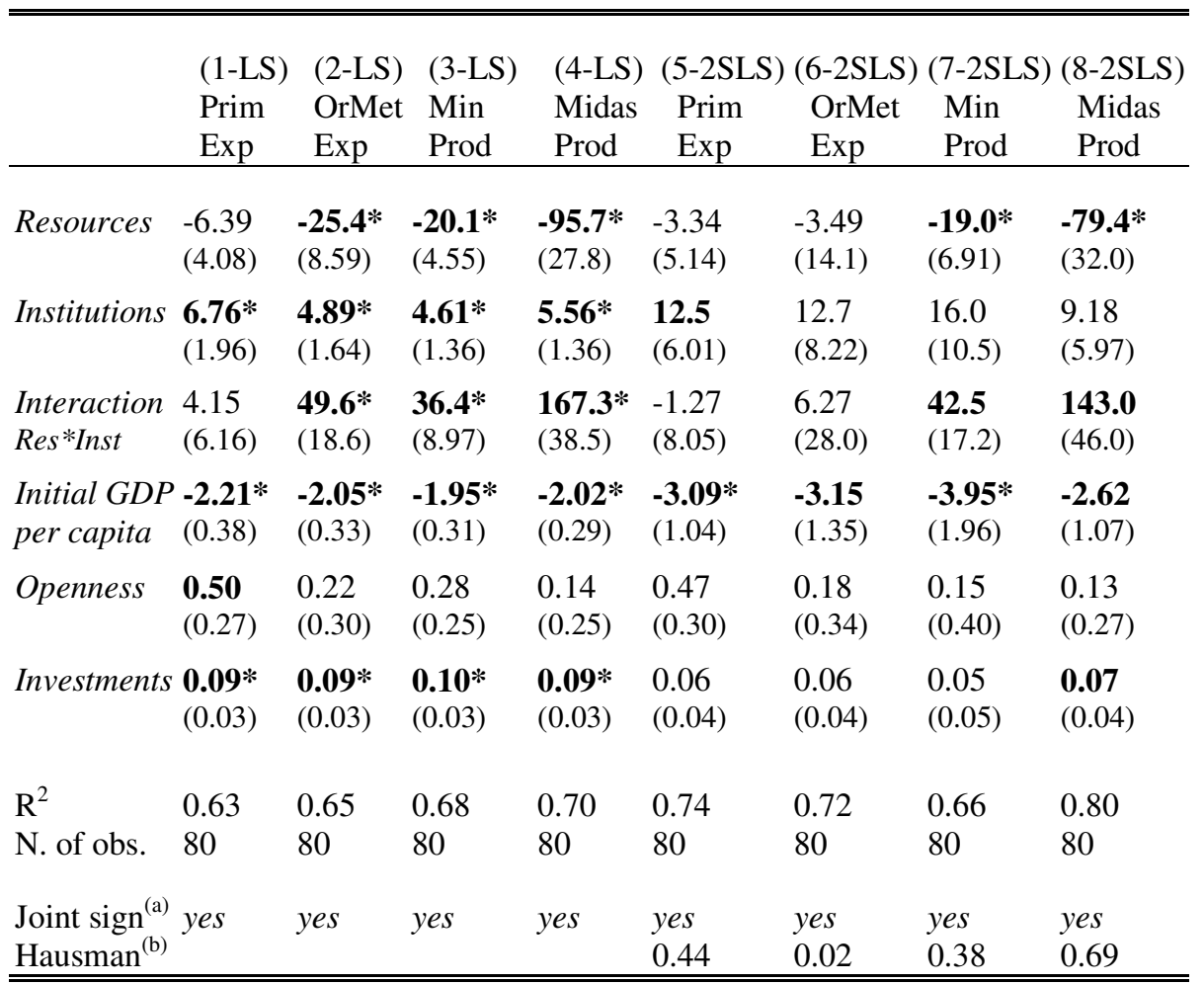

Figures in bold denotes significance at least at the 90 per cent level; * at the 99 per cent level. Robust standard errors in parentheses. The dependent variable is growth. All regressions include a constant term and regional dummies for Latin America and Subsaharan Africa (not reported). (a): Joint significance denotes whether the coefficient estimates of resources, institutions and their interaction are jointly significant. All are significant at the 99 per cent level, except the 2SLS estimates of PrimExp (96 per cent) and MinProd (98 per cent). (b): Hausman reports the p-values of the regression-based Hausman test for endogeneity as explained in the text. The hypothesis is that institutions are endogenous.

\section{Table 4. The main results}

Looking at our second hypothesis, on the one hand side, the more appropriable the resources are, the more negative is the effect of the resources themselves. On the other hand, the more technically appropriable the resources are, the more positive is the effect from the interaction with institutions. This supports our hypothesis that more appropriable resources are indeed more problematic, unless a country has sufficiently good institutions. Since the size of the natural resource variables differs greatly between them (though they all are expressed as share of GDP), a direct comparison of the coefficient estimates is not very informative. We evaluate the impact of different resources by calculating the marginal effects of a standard 
deviation change at different levels of institutional quality using the coefficients from Table 4, columns (1)-(4). Formally,

$$
\Delta \text { growth }=\left(\widehat{\beta}_{1}+\widehat{\beta}_{3} \widetilde{\text { Inst }}\right) \times s d N R,
$$

where $\widetilde{\text { Inst }}$ is the level of institutional quality, and $s d N R$ is a standard deviation change of the resource measures. ${ }^{18}$ For each of the four resource measures, we evaluate the growth impact for four different levels of institutional quality, the minimum level in the sample, 0.232 (the value for Democratic Republic of Congo), the average, 0.634 (between the value for Trinidad and Tobago and Costa Rica), the average level of institutions plus one standard deviation, 0.854 (between Hong Kong and Singapore), and the maximum, 0.995 (Switzerland). Table 5 reports the calculated effects. ${ }^{19}$ It illustrates both our hypotheses. First, reading the table top-down, given the production of natural resources, institutional quality is conductive to growth $(\mathrm{in}$ stitutional appropriability hypothesis). Second, reading left-right, the importance of good institutions increases in the technical appropriablility of resources (technically appropriability hypothesis).

\section{PrimExp OrMetExp MinProd MidasProd}

\begin{tabular}{lllll}
\hline & & & & \\
worst institutions & -0.548 & $\mathbf{- 0 . 9 4 6}$ & $\mathbf{- 1 . 1 2 7}$ & $\mathbf{- 1 . 4 2 5}$ \\
average institutions & -0.378 & $\mathbf{0 . 4 2 5}$ & $\mathbf{0 . 3 0 4}$ & $\mathbf{0 . 2 7 9}$ \\
aver. + one st.dev. institutions & -0.288 & $\mathbf{1 . 1 5 2}$ & $\mathbf{1 . 0 6 2}$ & $\mathbf{1 . 1 8 3}$ \\
best institutions & -0.228 & $\mathbf{1 . 6 2 9}$ & $\mathbf{1 . 5 6 0}$ & $\mathbf{1 . 7 7 6}$ \\
& & & & \\
\hline \hline
\end{tabular}

Table 5. Marginal effects of resources on growth (for different levels of institutional quality)

Given the recent insights provided by Acemoglu, Johnson and Robinson (2001) and Rodrik, Subramanian and Trebbi (2002) regarding the importance of the quality of institutions for economic development, it is crucial to further investigate the role of

\footnotetext{
${ }^{18}$ For example, using MinProd and the mean level of institutions (0.634) gives: $(-20.1+36.4 *$ $0.638) * 0.097=0.304$. The interpretation is that, ceteris paribus, a country with an average level of institutional quality would increase its annual growth rate by 0.3 per cent if it where to increase its mineral production by one standard deviation.

${ }^{19}$ The figures for PrimExp are based on insignificant estimates.
} 
institutions in our regression (1). There are basically two concerns. The first is that natural resources would determine institutions, which in turn would drive economic development - as hypothesised for example by Engerman and Sokoloff (2002) and Woolcook et al (2003). This would mean that our empirical model is misspecified and that our resource measures should instead be used to instrument for institutions.

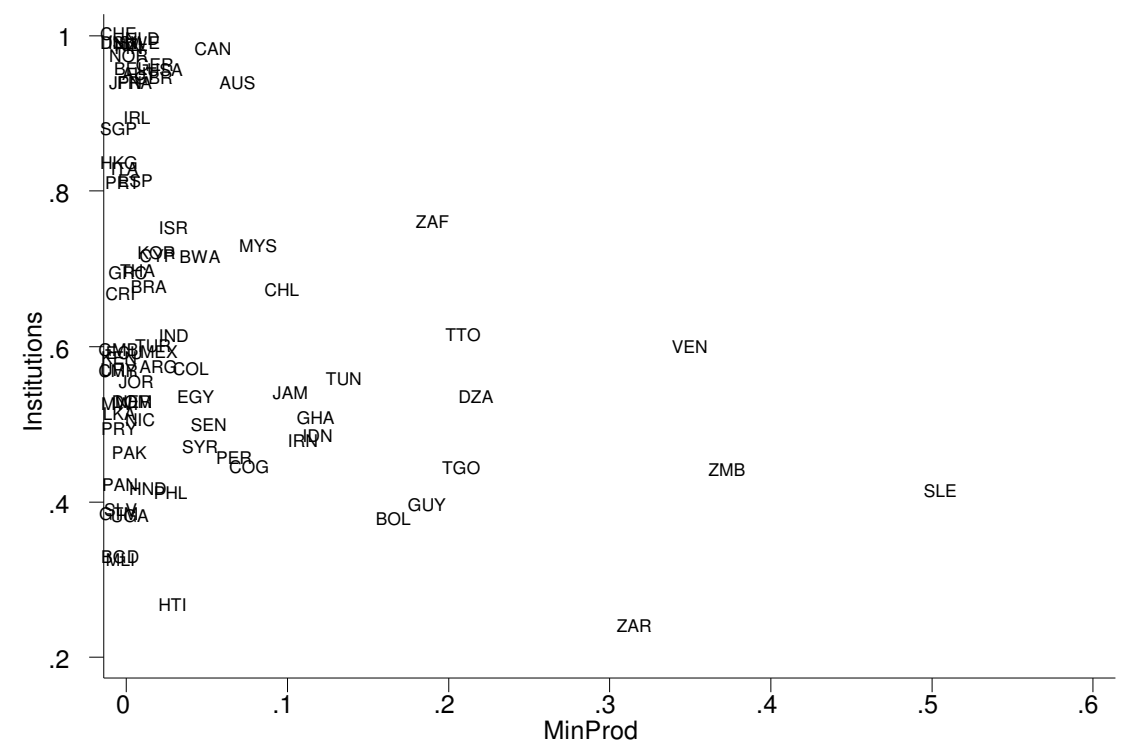

Figure 2. Plot of MinProd against institutions

Apart from Table 2 showing that the correlation between our different measures of natural resources with institutions is low, Figure 2 plots institutions against MinProd. Bearing in mind that MinProd is the most correlated measure of natural resources, we find no reason to believe that natural resources determine institutional quality.

The second concern arises from the fact that institutions could be correlated with the error term in our regression equation (1), so that our specification would suffer from endogeneity. To address this concern we perform a regression based Hausman test for endogeneity, which fails to reject that institutions and the interaction term of institutions and natural resources are exogenous in three out of 
four cases, as reported in Table $4 .^{20}$ Despite the scarce evidence of endogeneity, we instrument institutions (and the interaction) with latitude (and latitude interacted with resources) by using 2 SLS. ${ }^{21}$ Latitude, i.e. the distance from the Equator, is regarded as one of the best available instruments for institutions and its correlation with institutions is 0.75 in our 80 country sample. In Table 4, columns (5)-(8), we present the results from these estimations. (The first stage regressions are reported in Appendix D.)

For the highly technically appropriable (that are also production-based) measures of natural resources, these outcomes are similar to the results in columns (3)-(4) in Table 4 both regarding coefficient values and statistical significance. The two more general measures of resource endowment (PrimExp and OrMetExp) do, however, not maintain their statistical significance. The reason could be that they to a larger extent than the other proxies of resource endowment can be viewed as measures of development since they are indicators of the importance of primary (non manufactured) exports in the economy. That is, reverse causality could be affecting the estimates when using PrimExp and OrMetExp as measures of natural resources. Our conclusion is that, although the 2SLS estimates can be expected to be biased, they do not differ greatly from our LS regressions.

\footnotetext{
${ }^{20}$ In our structural model growth $=X_{i}^{\prime} \alpha+\beta_{1} N R_{i}+\beta_{2}$ Inst $_{i}+\beta_{3}\left(N R_{i} \times\right.$ Inst $\left._{i}\right)+\varepsilon_{i}$, we suspect Inst and hence $N R \times$ Inst to be endogenous. We run the first-stage reduced form regressions Inst $_{i}=X_{i}^{\prime} \alpha+\beta_{1} N R_{i}+v_{1}$ and $N R_{i} \times$ Inst $_{i}=X_{i}^{\prime} \alpha+\beta_{1} N R_{i}+v_{2}$ and include the Least Squares residuals $\widehat{v}_{1}$ and $\widehat{v}_{2}$ in the structural equation. In three out of four specifications (using PrimExp, MinProd and MidasProd) we fail to reject exogeneity of Inst and $N R \times I n s t$, i.e. the joint F-test for the LS-residuals is insignificant in the structural equation.

${ }^{21}$ We also tried to use settler mortality - as suggested in Acemoglu, Johnson and Robinson (2001) - as an instrument for institutions. This means, on the one hand, that we get an overidentified equation potentially leading to more precise estimates (given that usual assumptions hold). On the other hand, we now have a much smaller sample. Data on settler mortality only exist for 50 countries in our data set. The simple correlation between institutions and the log of settler mortality is -0.66 , but the correlation with latitude now falls to 0.47 . LS estimates in this smaller sample are similar to our main results. Even though, we still fail to reject the exogeneity of institutions (now with the exception of MidasProd) point estimates from this exercise are in line with those obtained when using latitude and latitude interacted with resources as excluded instruments. The Hansen-Sargan overidentification test never rejects the null of instrument viability (though the F-values in the first stage regressions are very low). These regressions results can be obtained from the authors upon request.
} 


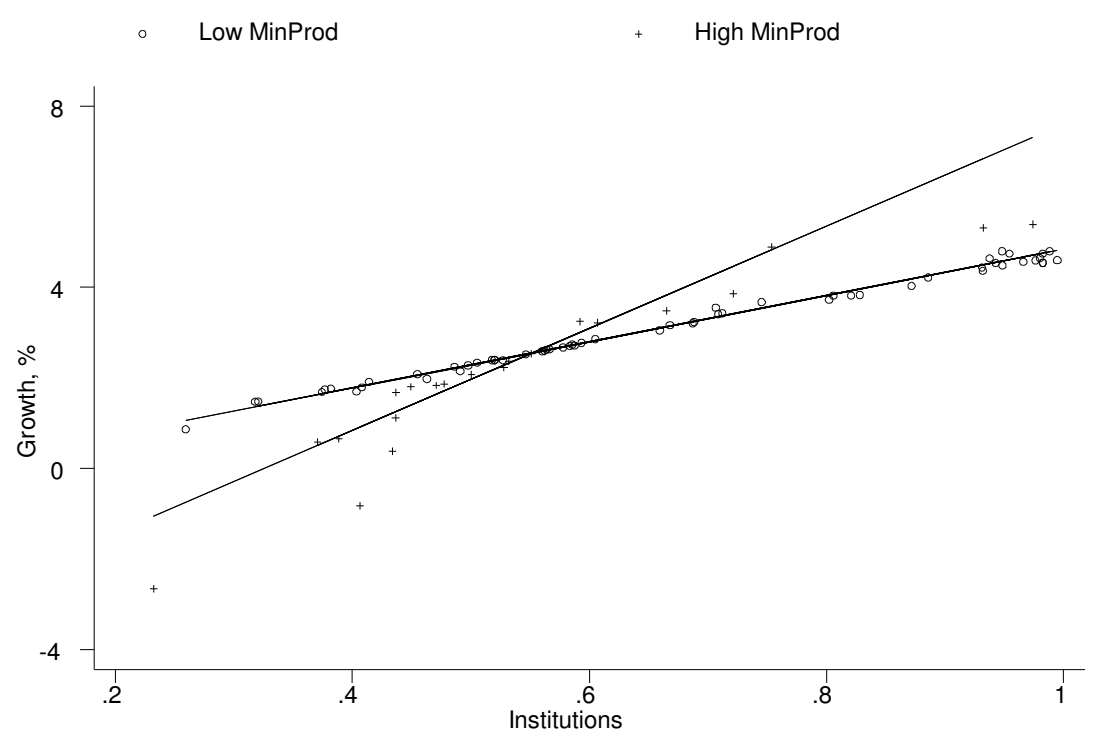

Figure 3. The partial effect of institutions on growth when dividing the sample into one less-than-average- and one above-the-average-natural resources

Figure 3 shows the partial effects of the combination of institutions and natural resources on economic growth. (Here we use MinProd as a measure of natural resources, while analogous figures for the other measures of natural resources are presented in Appendix C.) The sample is divided into two groups depending on whether the country has a natural resource level above the mean or not. Countries with less than mean production of minerals (MinProd) are represented by 'circles', while countries with higher than mean production of natural resources have a 'plus'. We fit two regression lines (one for each group) by using the regression coefficients in column (3) of Table 4, and the respective group averages. ${ }^{22}$

As hypothesised, countries with less natural resources score better than those with plenty of natural resources and poor institutions. Above the institutional threshold level (0.55), the partial contribution of resources is higher for a high MinProd country than for low MinProd country. Below the institutional cutoff the effect is reversed.

\footnotetext{
${ }^{22}$ Using MinProd for country $i$, in our structural model growth ${ }_{i}=\widehat{\beta}_{1} \overline{\operatorname{MinProd}}_{j}+\widehat{\beta}_{2}$ Inst $_{i}+$ $\widehat{\beta}_{3}\left(\overline{\operatorname{MinProd}}_{j} \times\right.$ Inst $\left._{i}\right)$, where $\overline{\operatorname{MinProd}}_{j}$ is the group mean of group $j$ with $j \in\{$ low; high $\}$. The mean of MinProd is 0.058, while the average value for those countries with MinProd less than the mean is 0.013 and the average for those countries with more than the mean is 0.182 .
} 


\section{Robustness of the results}

This section aims at challenging our results. In the previous section we had a wide sample of countries including both industrialised and developing countries. We now restrict the sample in various ways. We also show that dropping potential outliers does not affect our results.

Another part of this section addresses the concern that our results would be driven by a specific continent. Africa is often mentioned as the continent having the resource curse problem, so that one could suspect that excluding Africa would alter our results. But it does not influence our main results nor does excluding Latin America. We also show that our main results are robust to different proxies of institutional quality.

Furthermore, Appendix E contains some results when using FuelOrMetExp as a proxy for natural resource endowment. This is the only measure in the paper, apart from PrimExp, to contain oil (and other fuels) and thereby it could be interesting. The problem is that our sample contains almost none of the Organisation of Petroleum Exporting Countries' (OPEC) members due to lack of data, and hence it becomes odd to study the importance of oil in a sample that does not include either Afghanistan, Bahrain, Kuwait, Morocco, Nigeria, Saudi Arabia or Yemen to mention a few. Recently Sala-i-Martin and Subramanian (2003) argued that oil has been crucial in determining the development of Nigeria (among others) using data from 1980. Extending this data to comprise the 1970s is certainly one avenue for future research.

\subsection{Excluding the developed countries}

Although it is reassuring that our hypothesis has empirical support in a large sample of countries, much of the resource curse debate has been about the lack of development in resource-intensive developing countries during the last decades. Do our hypotheses hold when restricting the sample to contain only developing countries? This would seem quite challenging for our results since, by dropping richer countries, 
we exclude many countries with high institutional quality, some of which are rich in natural resources and may be driving the "positive" side of the interaction effect. Columns (1)-(4) in Table 6 report the results when exluding all the countries that where members of the OECD in $1975 .{ }^{23}$

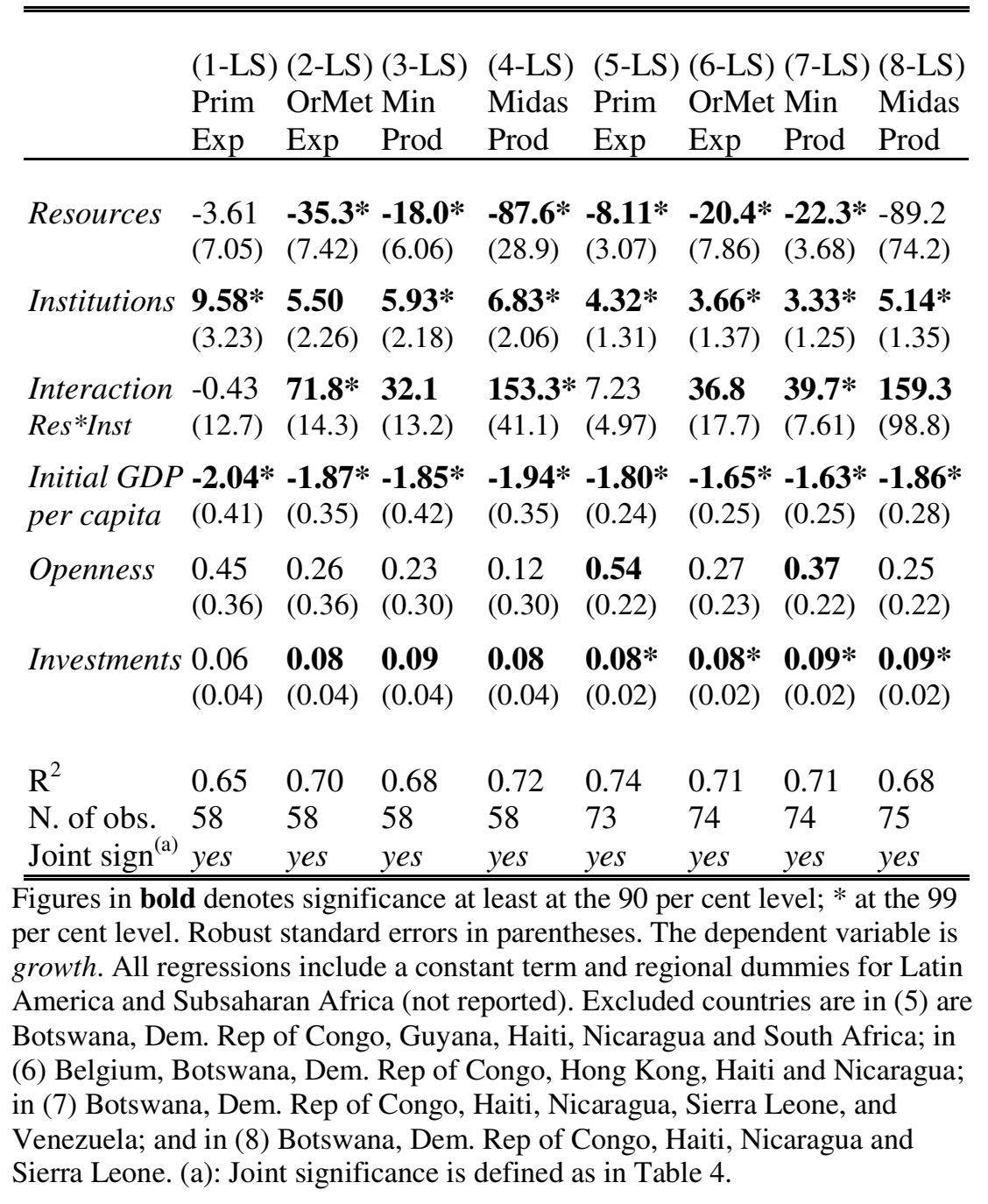

Table 6. The main results for developing countries (1)-(4) and when excluding outliers (5)-(8)

We find support for a non-monotonic relation between natural resources and growth even when considering the developing countries separately. Having good

\footnotetext{
${ }^{23}$ The countries excluded are Australia, Austria, Belgium, Canada, Denmark, Finland, France, Germany, Greece, Iceland, Ireland, Italy, Japan, Luxembourg, Netherlands, New Zealand, Norway, Portugal, Spain, Sweden, United Kingdom, and USA.
} 
institutions is still crucial when having plenty of highly technically appropriable resources. If anything, institutional quality by itself appears to be even more important for growth in developing countries. (For example, comparing the coefficients in column (4) in Table 6 with the corresponding column in Table 4, gives at hand that the coefficient for institutions is slightly bigger in the sample with only developing countries, while the resources and the interaction term coefficients are slightly smaller.)

\subsection{Are Botswana and Sierra Leone driving the results?}

In our sample there are of course countries that differ considerably from all the rest. Just eye-balling the data there are certain countries that are outliers either with respect to their growth performance over the period or their initial endowment of natural resources. Looking at Figures $4 \mathrm{~A}$ and $4 \mathrm{~B}$, obvious outliers in these respects are for the MidasProd measure of natural resources, for example, Botswana and Sierra Leone. ${ }^{24}$
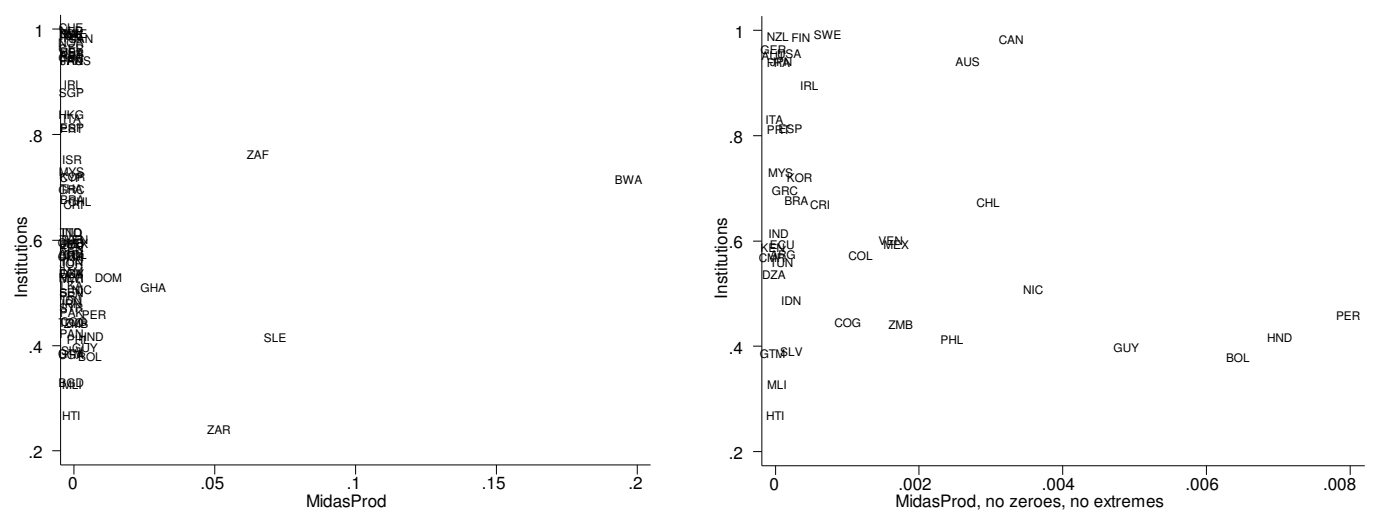

Figure 4A. Midas with the entire sample Figure 4B. Midas without extremes

In order to check for influential observations, i.e. observations with either a high leverage or a large residual, we use the DFITS index when estimating equation

\footnotetext{
${ }^{24}$ As seen from Figure 4A, MidasProd may be problematic in two ways. It has some clear outliers and many countries in the sample simply do not have any production of diamonds or precious metals. Apart from our exclusion of influential observations using DFITS, we also run regressions on MidasProd while excluding extreme observations. Excluding countries with zero production changes little. When also dropping all observations at least as high MidasProd as the Dominican Republic (leaving us a sample of 43 countries), the interaction term turns insignificant (p-value 0.14), though the three variables of interest are still jointly significant at the 99 per cent level. These estimates are available from the authors upon request.
} 
(1). Observations having a DFITS index larger than the absolute value of $2 \sqrt{\frac{k}{n}}$, where $k$ is the number of independent variables (including the constant) and $n$ is the number of observations, are excluded from the sample. ${ }^{25}$ Thereby, we obtain a specific sample for each measure of natural resource endowment. Columns (5)-(8) in Table 5 report the results and the countries that are excluded from the sample with each measure of natural resources. The outcome varies surprisingly little when excluding outliers.

\subsection{Is Africa (or Latin America) responsible for our results?}

While the previous section showed that the hypothesis in this paper provides a good explanation for the developing countries as a group, it could be that the results are entirely driven by some regions. Africa is known as a continent with abundant resources, in particular precious metals, but also for wars and low income per capita levels. A worry is, therefore, that our main results (presented in Table 4) could be driven by the development of the African continent. In Table 7, columns (1)-(4), we reestimate equation (1), but drop Africa from the sample. The results clearly indicate that good institutions are, in the presence of highly appropriable resources, quintessential for economic development also when excluding Africa.

Columns (5)-(8) in Table 7 show that the same is true when excluding Latin America from the sample. This is particularly reassuring since recent studies have pointed to the importance of initial factor endowments and other geographical factors for the shaping of institutions in Latin America. For example, Sokoloff and Engerman (2000) argue that the casual relation runs from the initial resource endowment that fosters a certain institutional setting, which can or cannot be beneficial for economic development in the long run. Sugar, coffee and cocoa economies in Latin America are often used to illustrate the point, but also mineral rich economies such as Chile and Peru. It is meant that the production of these resources is both valuable and easy to control for a small elite. This elite has all the incentives to

${ }^{25}{ }^{D F I T S} S_{i}=r_{i} \sqrt{\frac{h_{i}}{1-h_{i}}}$, where $r_{i}$ are the studentised residuals and $h_{i}$ is the leverage. 
ensure that the ownership of land remains concentrated in their hands, and this is most easily achieved by impeding the spread of education and democratic institutions. Thereby, it is suggested that initial resource endowment generate a strong path dependence that affects the pattern of economic development. That is, in the setting of this paper, one could suspect that natural resources have determined the institutional formation in these countries, Columns (5)-(8) in Table 7 indicate that our main results are not driven by the presence of Latin American countries, which is reassuring given their institutional history.

\begin{tabular}{|c|c|c|c|c|c|c|c|c|}
\hline & $\begin{array}{l}(1-\mathrm{LS}) \\
\text { Prim } \\
\text { Exp } \\
\end{array}$ & $\begin{array}{l}(2-\mathrm{LS}) \\
\text { OrMet } \\
\text { Exp }\end{array}$ & $\begin{array}{l}(3-\mathrm{LS}) \\
\text { Min } \\
\text { Prod }\end{array}$ & $\begin{array}{l}\text { (4-LS) } \\
\text { Midas } \\
\text { Prod } \\
\end{array}$ & $\begin{array}{l}(5-\mathrm{LS}) \\
\text { Prim } \\
\text { Exp } \\
\end{array}$ & $\begin{array}{l}(6-\mathrm{LS}) \\
\text { OrMet } \\
\text { Exp }\end{array}$ & $\begin{array}{l}(7-\text { LS }) \\
\text { Min } \\
\text { Prod } \\
\end{array}$ & $\begin{array}{l}(8-\mathrm{LS}) \\
\text { Midas } \\
\text { Prod } \\
\end{array}$ \\
\hline Resources & $\begin{array}{l}-6.55 \\
(5.06)\end{array}$ & $\begin{array}{l}-6.91 \\
(5.57)\end{array}$ & $\begin{array}{l}\mathbf{- 1 4 . 2} \\
(6.56)\end{array}$ & $\begin{array}{l}-\mathbf{4 0 4 . 0} * \\
(28.9)\end{array}$ & $\begin{array}{l}-6.32 \\
(4.93)\end{array}$ & $\begin{array}{l}\mathbf{- 2 7 . 1} * \\
(10.8)\end{array}$ & $\begin{array}{l}-\mathbf{2 1 . 6} * \\
(4.02)\end{array}$ & $\begin{array}{l}\mathbf{- 8 7 . 3 *} \\
(29.3)\end{array}$ \\
\hline Institutions & $\begin{array}{l}\mathbf{5 . 3 7 *} \\
(1.55)\end{array}$ & $\begin{array}{l}\mathbf{5 . 5 0} * \\
(1.50)\end{array}$ & $\begin{array}{l}\mathbf{5 . 0 8 *} \\
(1.48)\end{array}$ & $\begin{array}{l}\mathbf{5 . 5 4} * \\
(1.36)\end{array}$ & $\begin{array}{l}7.24 * \\
(2.31)\end{array}$ & $\begin{array}{l}\mathbf{5 . 3 7 *} \\
(1.88)\end{array}$ & $\begin{array}{l}\text { 4.83* } \\
(1.40)\end{array}$ & $\begin{array}{l}\mathbf{5 . 6 1} * \\
(1.35)\end{array}$ \\
\hline $\begin{array}{l}\text { Interaction } \\
\text { Res*Inst }\end{array}$ & $\begin{array}{l}4.43 \\
(6.71)\end{array}$ & $\begin{array}{l}12.6 \\
(14.9)\end{array}$ & $\begin{array}{l}\mathbf{2 3 . 0} \\
(11.3)\end{array}$ & $\begin{array}{l}\mathbf{6 2 9 . 6} \\
(354.1)\end{array}$ & $\begin{array}{l}4.79 \\
(6.95)\end{array}$ & $\begin{array}{l}49.2 \\
(24.1)\end{array}$ & $\begin{array}{l}\text { 41.7* } \\
(7.49)\end{array}$ & $\begin{array}{l}\text { 155.0* } \\
(40.6)\end{array}$ \\
\hline $\begin{array}{l}\text { Initial GDP } \\
\text { per capita }\end{array}$ & $\begin{array}{l}\mathbf{- 2 . 0 7 *} \\
(0.32)\end{array}$ & $\begin{array}{l}\mathbf{- 2 . 0 8 *} \\
(0.32)\end{array}$ & $\begin{array}{l}\mathbf{- 2 . 0 3 *} \\
(0.34)\end{array}$ & $\begin{array}{l}\mathbf{- 2 . 1 0} * \\
(0.32)\end{array}$ & $\begin{array}{l}\mathbf{- 2 . 2 9 *} \\
(0.44)\end{array}$ & $\begin{array}{l}\mathbf{- 2 . 1 0} * \\
(0.36)\end{array}$ & $\begin{array}{l}\mathbf{- 1 . 9 8 *} \\
(0.28)\end{array}$ & $\begin{array}{l}\mathbf{- 2 . 0 1} \\
(0.26)\end{array}$ \\
\hline Openness & $\begin{array}{l}\mathbf{0 . 5 1} \\
(0.26)\end{array}$ & $\begin{array}{l}0.26 \\
(0.31)\end{array}$ & $\begin{array}{l}0.30 \\
(0.27)\end{array}$ & $\begin{array}{l}0.30 \\
(0.25)\end{array}$ & $\begin{array}{l}\mathbf{0 . 6 0} \\
(0.29)\end{array}$ & $\begin{array}{l}0.42 \\
(0.33)\end{array}$ & $\begin{array}{l}\mathbf{0 . 4 7} \\
(0.27)\end{array}$ & $\begin{array}{l}0.37 \\
(0.27)\end{array}$ \\
\hline Investments & $\begin{array}{l}\mathbf{0 . 0 8 *} \\
(0.03)\end{array}$ & $\begin{array}{l}\mathbf{0 . 0 9 *} \\
(0.03)\end{array}$ & $\begin{array}{l}\mathbf{0 . 0 9} * \\
(0.03)\end{array}$ & $\begin{array}{l}\mathbf{0 . 0 9} * \\
(0.03)\end{array}$ & $\begin{array}{l}\mathbf{0 . 0 9 *} \\
(0.03)\end{array}$ & $\begin{array}{l}\mathbf{0 . 1 0} * \\
(0.03)\end{array}$ & $\begin{array}{l}\mathbf{0 . 1 1} * \\
(0.03)\end{array}$ & $\begin{array}{l}\mathbf{0 . 0 9} * \\
(0.02)\end{array}$ \\
\hline $\begin{array}{l}\mathrm{R}^{2} \\
\text { N. of obs. } \\
\text { Joint sign }^{(a)}\end{array}$ & $\begin{array}{l}0.60 \\
64 \\
\text { yes }\end{array}$ & $\begin{array}{l}0.58 \\
64 \\
\text { yes }\end{array}$ & $\begin{array}{l}0.59 \\
64 \\
\text { yes }\end{array}$ & $\begin{array}{l}0.60 \\
64 \\
\text { yes }\end{array}$ & $\begin{array}{l}0.71 \\
58 \\
\text { yes }\end{array}$ & $\begin{array}{l}0.74 \\
58 \\
y e s\end{array}$ & $\begin{array}{l}0.78 \\
58 \\
\text { yes }\end{array}$ & $\begin{array}{l}0.81 \\
58 \\
\text { yes }\end{array}$ \\
\hline
\end{tabular}

Table 7. The main results when excluding Subsaharan Africa (1)-(4) and Latin America (5)-(8) 


\subsection{Robustness to other institutional measures}

The last robustness check consists in using alternative measures of institutional quality. Even though institutional measures are highly correlated as reported in Table 8 , we test if our basic equation (1) holds with a variety of institutional measures.

\begin{tabular}{l|cccccc} 
& Institutions & Polity75 & PropRight84 Rlaw84 Exprop84 & Repud84 \\
\hline Polity75 & $\mathbf{0 . 7 3}$ & & & & & \\
PropRight84 & $\mathbf{0 . 9 8 *}$ & $\mathbf{0 . 7 3} *$ & & & & \\
Rlaw84 & $\mathbf{0 . 9 3}^{*}$ & $\mathbf{0 . 6 8}^{*}$ & $\mathbf{0 . 9 4}^{*}$ & & & \\
Exprop84 & $\mathbf{0 . 9 2}^{*}$ & $\mathbf{0 . 6 9}^{*}$ & $\mathbf{0 . 9 5}^{*}$ & $\mathbf{0 . 8 7}^{*}$ & & \\
Repud84 & $\mathbf{0 . 9 0}^{*}$ & $\mathbf{0 . 6 9}^{*}$ & $\mathbf{0 . 9 3}^{*}$ & $\mathbf{0 . 8 3}^{*}$ & $\mathbf{0 . 9 3}^{*}$ & \\
Rlaw98 & $\mathbf{0 . 8 9}^{*}$ & $\mathbf{0 . 8 9}^{*}$ & $\mathbf{0 . 8 5}^{*}$ & $\mathbf{0 . 8 3}^{*}$ & $\mathbf{0 . 7 8}^{*}$ & $\mathbf{0 . 7 7}^{*}$ \\
\hline
\end{tabular}

Figures in bold denotes significance at least at the 90 per cent level; * at the 99 per cent level.

Table 8. Correlation matrix for other institutional variables

More specifically, we use seven measures ranging from polity 75 from the Polity IV data set to Rule of Law in 1998 (rlaw98) from Kaufmann, Kraay and Zoido-Lobáton (2002). In order to reduce the number of tables, we only report the outcomes when using MidasProd as the measure of initial natural resource endowment. Table 9 reports the regression results and while the impact of the natural resource measure by itself on growth is not significant in three out of six cases, the interaction effect of MidasProd and institutions is always significant. ${ }^{26}$ This means that our results do not appear to be sensitive to the chosen measure of institutional quality.

\footnotetext{
${ }^{26}$ Note that the quantitative effects on growth are not directly comparable since the scaling of the institutional variables differs between them.
} 


\begin{tabular}{|c|c|c|c|c|c|c|}
\hline & $\begin{array}{l}\text { (1-LS) } \\
\text { Polity75 }\end{array}$ & $\begin{array}{l}(2-\mathrm{LS}) \\
\text { Prop } \\
\text { Right84 }\end{array}$ & $\begin{array}{l}\text { (3-LS) } \\
\text { RLaw84 }\end{array}$ & $\begin{array}{l}\text { (4-LS) } \\
\text { Exprop84 }\end{array}$ & $\begin{array}{l}(5-\mathrm{LS}) \\
\text { Repud84 }\end{array}$ & $\begin{array}{l}(6-\mathrm{LS}) \\
\text { Rlaw98 }\end{array}$ \\
\hline MidasProd & $\begin{array}{l}-12.9 \\
(12.8)\end{array}$ & $\begin{array}{l}\mathbf{- 1 0 2 . 2} * \\
(32.2)\end{array}$ & $\begin{array}{l}-69.2 \\
(48.9)\end{array}$ & $\begin{array}{l}-\mathbf{1 5 4 . 2} * \\
(32.5)\end{array}$ & $\begin{array}{l}\mathbf{- 1 5 4 . 8} * \\
(57.2)\end{array}$ & $\begin{array}{l}7.90 \\
(4.99)\end{array}$ \\
\hline Institutions & $\begin{array}{l}0.03 \\
(0.03)\end{array}$ & $\begin{array}{l}4.27 * \\
(1.19)\end{array}$ & $\begin{array}{l}\mathbf{0 . 3 5} \\
(0.18)\end{array}$ & $\begin{array}{l}\text { 0.36* } \\
(0.10)\end{array}$ & $\begin{array}{l}\mathbf{0 . 4 3} * \\
(0.11)\end{array}$ & $\begin{array}{l}\mathbf{0 . 8 6} * \\
(0.26)\end{array}$ \\
\hline $\begin{array}{l}\text { Interaction } \\
\text { Midas*Inst }\end{array}$ & $\begin{array}{l}\mathbf{4 . 0 7} * \\
(1.47)\end{array}$ & $\begin{array}{l}\text { 184.9* } \\
(48.6)\end{array}$ & $\begin{array}{l}\mathbf{1 8 . 1} \\
(9.80)\end{array}$ & $\begin{array}{l}\mathbf{2 5 . 3} * \\
(4.60)\end{array}$ & $\begin{array}{l}\mathbf{2 9 . 3} * \\
(9.52)\end{array}$ & $\begin{array}{l}31.1 * \\
(6.53)\end{array}$ \\
\hline $\begin{array}{l}\text { Initial GDP } \\
\text { per capita }\end{array}$ & $\begin{array}{l}\mathbf{- 1 . 1 4} * \\
(0.24)\end{array}$ & $\begin{array}{l}\mathbf{- 1 . 9 6 *} \\
(0.30)\end{array}$ & $\begin{array}{l}\mathbf{- 1 . 4 3 *} \\
(0.36)\end{array}$ & $\begin{array}{l}\mathbf{- 1 . 5 4} * \\
(0.22)\end{array}$ & $\begin{array}{l}\mathbf{- 1 . 8 0 *} \\
(0.25)\end{array}$ & $\begin{array}{l}\mathbf{- 1 . 5 0 *} \\
(0.26)\end{array}$ \\
\hline Openness & $\begin{array}{l}0.02 \\
(0.23)\end{array}$ & $\begin{array}{l}0.14 \\
(0.25)\end{array}$ & $\begin{array}{l}0.19 \\
(0.23)\end{array}$ & $\begin{array}{l}0.13 \\
(0.24)\end{array}$ & $\begin{array}{l}0.05 \\
(0.27)\end{array}$ & $\begin{array}{l}-0.02 \\
(0.23)\end{array}$ \\
\hline Investments & $\begin{array}{l}\mathbf{0 . 1 2} * \\
(0.03)\end{array}$ & $\begin{array}{l}\mathbf{0 . 0 9 *} \\
(0.02)\end{array}$ & $\begin{array}{l}\mathbf{0 . 0 9 *} \\
(0.03)\end{array}$ & $\begin{array}{l}\mathbf{0 . 0 9} * \\
(0.02)\end{array}$ & $\begin{array}{l}\mathbf{0 . 1 1} * \\
(0.02)\end{array}$ & $\begin{array}{l}\mathbf{0 . 1 0} * \\
(0.02)\end{array}$ \\
\hline $\begin{array}{l}\mathrm{R}^{2} \\
\text { N. of obs. } \\
\text { Joint sign }\end{array}$ & $\begin{array}{l}0.63 \\
78 \\
\text { yes }\end{array}$ & $\begin{array}{l}0.69 \\
76 \\
y e s\end{array}$ & $\begin{array}{l}0.62 \\
76 \\
\text { yes }\end{array}$ & $\begin{array}{l}0.69 \\
76 \\
\text { yes }\end{array}$ & $\begin{array}{l}0.68 \\
76 \\
\text { yes }\end{array}$ & $\begin{array}{l}0.69 \\
80 \\
\text { yes }\end{array}$ \\
\hline
\end{tabular}

Table 9. The main results with other institutional measures

\section{Summary and concluding remarks}

Kenneth Kaunda, the former President of Zambia, has been quoted to say "We are in part to blame, but this is the curse of being born with a copper spoon in our mouth", referring to Zambia's poor economic performance. ${ }^{27}$ In another quote referring to the deterministic, negative effects of having abundant resources, Leonardo Simão (Minister of Foreign Affairs of Mozambique) has said, "Mozambique is different [from Angola]. We are fortunate not to have oil and not to have diamonds". ${ }^{28}$ This paper suggests that such statements need modification. The problem for Zambia, and

\footnotetext{
${ }^{27} \operatorname{Ross}(1999)$.

${ }^{28}$ Speech delivered at the Swedish Institute of International Affairs, Stockholm, Sweden on June 18, 1999.
} 
many other countries, lies not in the resource richness per se, but in the combination of having poor institutions and resource wealth. Our results indicate that a sufficient improvement of institutional quality turns resource abundance into an asset rather than a curse.

Furthermore, we have shown that the type of natural resources that a country possesses is of crucial importance. The negative effects of poor institutional quality, in our words high institutional appropriability, are much more severe in countries rich in technically appropriable resources compared to those rich in other natural resources. Conversely, the rewards of having good institutions are greatest for the countries with plenty of technically appropriable resources.

For all our measures of mineral-intensity, the positive interaction term always outweighs the negative effect of the resources themselves, and the effect is highly significant. We find the strongest and most significant effects when using the value of production of precious metals and diamonds.

What are the quantitative implications of our findings? Taking the point estimates seriously, our results suggests that if a country, such as Sierra Leone (with an average growth rate of -2.05 per cent since 1975$)$ would manage to close its institutional gap with a country like Botswana (with a growth rate of 4.99 per cent over the period), then its yearly growth rate would also approach that of Botswana. Thus, Sierra Leone has the potential to perform like Botswana, but they lack the institutional setting to do so.

This paper challenges the traditional resource curse, which taken literally would simply suggest that a country would be better off without its resources. We find this hard to believe. By identifying a non-montone relationship between institutions and resources, and the particular role of certain types of minerals, we show that it is possible to reverse the curse.

Even though we have done what we can to check the validity of our econometric specification, we do not provide a precise explanation of the empirical relationship we find. In the beginning of this paper we sketched a theory of broad mechanisms 
for why institutions would matter for growth and increasingly so in countries with technically appropriable resources. We hypothesised that the easier it is to grab valuable resources, the more important it is to have institutions preventing appropriative behavior. Otherwise, conflicts and corruption will harm the economy.

The literal policy advice of this paper would thus be to "Get your institutions right, especially if you have plenty of diamonds and precious metals". This is of course not very informative in terms of implementability, but it does suggest that countries can do something more to improve their economic situation than giving away their resources - as suggested by the resource curse hypothesis.

\section{References}

[1] Acemoglu, D., Johnson, S., and J. A. Robinson. (2001). The Colonial Origins of Comparative Development: An Empirical Investigation. American Economic Review 91(5): 1396-1401.

[2] Auty, R. M. (1993). Sustaining Development in Mineral Economies: The Resource Curse Thesis. London and New York: Routledge.

[3] Auty, R. M. (1997). Natural Resource Endowment, the State and Development Strategy. Journal of International Development 9(4): 651-663.

[4] Barro, R. J. and Lee, J. (2000). International Data on Educational Attainment: Updates and Implications. Manuscript, Harvard University, August 2000.

[5] Bates, R. H. (2001). Prosperity and Violence: The Political Economy of Development. W. W. New York and London: Norton \& Company.

[6] Campbell, G. (2002). Blood Diamonds: Tracing the Deadly Path of the World's Most Precious Stones. Boulder: Westview Press.

[7] Collier P. and A. Hoeffler. (1998). On Economic Causes of Civil War. Oxford Economic Papers 50: 563-573.

[8] Collier P. and A. Hoeffler. (2002). Greed and Grievance in Civil War. Centre for the Study of African Economies Working Paper 2002-01.

[9] Corden, W.M. and J.P. Neary. (1982). Booming Sector and De-Industrialisation in a Small Open Economy. Economic Journal 92: 825-48. 
[10] Engerman, S. L., and K. L. Sokoloff. (2002). Factor Endowments, Inequality, and the Path of Development Among the New World Economies. Work in Progress.

[11] Easterly, W. and R. Levine (2002). Tropics, Germs and Crops: How Endowments Influence Economic Development. NBER Working Paper 9106.

[12] Gelb, A. H. (1988). Windfall Gains: Blessing or Curse?. New York: Oxford University Press.

[13] Gylfason, T., Herbertson, T.T. and G. Zoega. (1999). "A mixed blessing: Natural resources and economic growth". Macroeconomic Dynamics 3:204-225.

[14] Isham, J., Woolcook, M., Pritchett, L. and G. Busby. (2003). "The Varieties of Resource Experience: How Natural Resource Export Structures Affect the Political Economy of Economic Growth". Middlebury College Discussion Paper 03-08.

[15] Karl, T. L. (1997). The Paradox of Plenty: Oil Booms and Petro-States. Berkeley: University of California Press.

[16] Kaufmann, D., Kraay, A. and P. Zoido-Lobáton. (2002). Governance Matters II - Updated Indicators 2000/01. World Bank Policy Research Working Paper 2772 .

[17] Keefer, P. and Knack, S. (2002). Polarization, Politics, and Property Rights: Links between Inequality and Growth. Public Choice 111: 127-154.

[18] Knack, S. and P. Keefer. (1995). Institutions and Economic Performance: Cross-Country Tests Using Alternative Measures. Economics and Politics 7(3): 207-227.

[19] La Porta, R., Lopez-de-Silanes, F., Shleifer, A., and R. W. Vishny. (1998). The Quality of Government. Manuscript, Harvard University, August 1998.

[20] Lane, P. R. and A. Tornell. (1999). The Voracity Effect. American Economic Review 89(1): 22-46.

[21] Marshall, M. G. and K. Jaggers. (2000). Polity IV Project. Integrated Network for Societal Conflict Research (INSCR) Program. Center for International Development and Conflict Management (CIDCM). www.bsos.umd.edu/cidcm/inscr/polity

[22] Matsuyama, K. (1992). "Agricultural Productivity, Comparative Advantage and Economic Growth". Journal of Economic Theory 58:317-334.

[23] Mehlum H. Moene K. and R. Torvik. (2002). "Institutions and the Resource Curse". Mimeo. 
[24] Neary, J. P. and S. J. G. van Wijnbergen. (1986). Natural Resources and the Macroeconomy. (pp. 1-11). Cambridge, Mass. MIT Press.

[25] Robinson, J., Torvik, R. and T. Verdier. (2002). "Political Foundations of the Resource Curse". CEPR Discussion paper 3422.

[26] Rodrik, D. (1999). "Where Did All the Growth Go? External Shocks, Social Conflict, and Growth Collapses". Journal of Economic Growth 4(4): 385-412.

[27] Rodrik, D., Subramanian, A. and F. Trebbi. (2002). "Institutions Rule: The Primacy of Institutions over Geography and Integration in Economic Development". CEPR Discussion Paper 3643.

[28] Ross, M. L. (2001). "Does Oil Hinder Democracy?". World Politics 53(3):325361.

[29] Ross, M. L. (1999). The Political Economy of the Resource Curse. World Politics 51(2): 297-322.

[30] Sachs, J. D., and A. M. Warner. (1995) Natural Resource Abundance and Economic Growth. NBER Working Paper 5398.

[31] Sala-i-Martin, X. and A. Subramanian, 2003, "Addressing the natural resource curse: An illustration from Nigeria", NBER working paper 9804.

[32] Sokoloff, K. L., and S. L. Engerman. (2000). History Lessons: Institutions, Factor Endowments, and Paths of Development in the New World. Journal of Economic Perspectives 14(3):217-232.

[33] UNCTAD. (various years). Handbook of international trade and development statistics. United Nations.

[34] U.S. Bureau of mines (Department of the Interior). (various years). Minerals Yearbook. Washington, DC. U. S. Government printing office.

[35] U.S. Geological Survey (Department of the Interior). (1999). Metal Prices in the United States through 1998. Washington, DC. U. S. Government printing office; available at http://minerals.usgs.gov.

[36] Woolcook, M., Pritchett, L. and J. Isham. (2001). "The Social Foundations of Poor Economic Growth in Resource Rich Economies" in R. M. Auty (ed). Resource Abundance and Economic Development. New York: Oxford University Press.

[37] Wright, G. (2001). Resource-Based Growth Then and Now. Stanford University. (Prepared for the World Bank Project "Patterns of Integration in the Global Economy"). 


\section{Appendix A. Definitions and descriptive statistics}

\begin{tabular}{|c|c|}
\hline Algeria & Jamaica \\
\hline Argentina & Japan \\
\hline Australia & Jordan \\
\hline Austria & Kenya \\
\hline Bangladesh & Korea, Republic of \\
\hline Belgium & Malawi \\
\hline Bolivia & Malaysia \\
\hline Botswana & Mali \\
\hline Brazil & Mexico \\
\hline Cameroon & Netherlands \\
\hline Canada & New Zealand \\
\hline Chile & Nicaragua \\
\hline Colombia & Niger \\
\hline Congo, Dem. Rep* & Norway \\
\hline Congo, Republic of & Pakistan \\
\hline Costa Rica & Panama \\
\hline Cyprus* & Paraguay \\
\hline Denmark & Peru \\
\hline Dominican Republic & Philippines \\
\hline Ecuador & Portugal \\
\hline Egypt & Senegal \\
\hline El Salvador & Sierra Leone* \\
\hline Finland & Singapore* \\
\hline France & South Africa \\
\hline Gambia & Spain \\
\hline Germany & Sri Lanka \\
\hline Ghana & Sweden \\
\hline Greece & Switzerland \\
\hline Guatemala & Syria \\
\hline Guyana & Thailand \\
\hline Haiti & Togo \\
\hline Honduras & Trinidad and Tobago \\
\hline Hong Kong & Tunisia \\
\hline Iceland & Turkey \\
\hline India & Uganda \\
\hline Indonesia & United Kingdom \\
\hline Iran & Uruguay \\
\hline Ireland & USA \\
\hline Israel & Venezuela \\
\hline Italy & Zambia \\
\hline
\end{tabular}

* $\overline{\text { These countries are, due to data availability, measured }}$ until 1996.

Table A1. Countries in the sample 


\begin{tabular}{|c|c|}
\hline PrimExp & $\begin{array}{l}\text { Share of exports of primary products in GNP in 1971. Source: Sachs } \\
\text { and Warner (1995), where it is labelled SXP. }\end{array}$ \\
\hline FuelOrMetExp & $\begin{array}{l}\text { Value of export of ores, metals and fuels as share of GDP in } 1975 . \\
\text { Source: Unctad }(1975,1979)\end{array}$ \\
\hline OrMetExp & $\begin{array}{l}\text { Value of export of ores and metals as share of GDP in } 1975 . \text { Source: } \\
\text { Unctad }(1975,1979)\end{array}$ \\
\hline MinProd & $\begin{array}{l}\text { Share of mineral production (does not include fuels) in GNP in 1971, } \\
\text { where "mineral production" is the production value of the } 23 \text { highest } \\
\text { valued minerals in the world as of } 1973 \text {. Source: Sachs and Warner } \\
\text { (1995) where it is labelled SNR. }\end{array}$ \\
\hline MidasProd & $\begin{array}{l}\text { Value of production of gold, silver, and diamonds as share of GDP, } \\
\text { average } 1972 \text { to 1980. Source: Own calculations based on US Bureau of } \\
\text { Mines (various years) and US Geological Survey (1999). }\end{array}$ \\
\hline Institutions & $\begin{array}{l}\text { Is derived from the IRIS data originally constructed by Knack and } \\
\text { Keefer (1995) based on data from the International Country Risk Guide. } \\
\text { The five Property Right Index components are Quality of the } \\
\text { bureaucracy, Corruption in government, and Rule of law, scoring from } \\
\text { 0-6, and Risk of expropriation of private investment, and Repudiation } \\
\text { of contracts by government, scored 0-10. Higher scores mean better } \\
\text { quality, lower corruption and lower risks. By transforming the first } \\
\text { three into ten point scales (as in Keefer and Knack, 2002), the } \\
\text { (unweighted) sum gives an index from } 0 \text { to 50, which we rescale into an } \\
\text { index between zero and one. We use the average over the period } 1984 \\
\text { to 1998. Source: Keefer and Knack (2002). }\end{array}$ \\
\hline Growth & $\begin{array}{l}\text { Average yearly growth rate (in per cent) between } 1975 \text { and } 1998 . \\
\text { Calculated as [ln(rgdpch98)-ln(rgdpch75)* 100/20], where rgdpch is the } \\
\text { PPP-adjusted GDP per capita between } 1975 \text { and 1998. Source: Penn } \\
\text { World Table, Mark 6.1. }\end{array}$ \\
\hline $\begin{array}{l}\text { Initial GDP } \\
\text { per capita }\end{array}$ & $\begin{array}{l}\text { Real GDP per capita in constant dollars (Chain index) expressed in } \\
\text { international prices }[\ln (\operatorname{rgdpch} 75)] . \text { Source: Penn World Table, Mark } \\
6.1\end{array}$ \\
\hline Initial schooling & $\begin{array}{l}\text { Average schooling years in the total population 1975. Source: Barro } \\
\text { and Lee (2000). }\end{array}$ \\
\hline Openness & $\begin{array}{l}\text { Natural logarithm of average openness (openc) } 1975 \text { to } 1998 \text {. Source: } \\
\text { Penn World Table, Mark 6.1. }\end{array}$ \\
\hline Investments & $\begin{array}{l}\text { Average investment share of real GDP per capita (ki) } 1975 \text { to } 1998 . \\
\text { Source: Penn World Table, Mark 6.1. }\end{array}$ \\
\hline Latitude & $\begin{array}{l}\text { The absolute value of the latitude of the country, scaled to take values } \\
\text { between } 0 \text { and } 1 \text {. Source: La Porta et al. (1998). }\end{array}$ \\
\hline Polity75 & $\begin{array}{l}\text { Combined Polity Score for } 1975 \text { ranging from }+10 \text { (strongly } \\
\text { democratic) to }-10 \text { (strongly autocratic). Source: Marshall and Jaggers } \\
(2000) \text {. }\end{array}$ \\
\hline PropRight84 & Institutions but only for 1984. Source: Keefer and Knack (2002). \\
\hline RLaw84 & $\begin{array}{l}\text { Rule of law index in 1984, scoring from 0-6. Source: Keefer and } \\
\text { Knack (2002). }\end{array}$ \\
\hline RLaw98 & Rule of law index. Source: Kaufmann et al (2002). \\
\hline Exprop84 & $\begin{array}{l}\text { Risk of expropriation of private investment in 1984, scored 0-10. } \\
\text { Source: Keefer and Knack (2002). }\end{array}$ \\
\hline Repudate84 & $\begin{array}{l}\text { Repudiation of contracts by government in } 1984 \text {, scored } 0-10 \text {. Source: } \\
\text { Keefer and Knack (2002). }\end{array}$ \\
\hline
\end{tabular}

Table A2. Definitions and sources of variables 


\begin{tabular}{lccccc}
\hline Variable & Obs & Mean & Std Dev & Min & Max \\
& & & & & \\
\hline & 80 & 1.533 & 1.965 & -5.391 & 5.968 \\
Growth & 80 & 0.121 & 0.101 & 0.006 & 0.543 \\
PrimExp & 80 & 0.041 & 0.068 & 0 & 0.357 \\
OrMetExp & 80 & 0.058 & 0.097 & 0 & 0.509 \\
MinProd & 80 & 0.006 & 0.025 & 0 & 0.198 \\
MidasProd & 80 & 0.638 & 0.215 & 0.232 & 0.995 \\
Institutions & 80 & 8.332 & 0.980 & 6.389 & 9.923 \\
Initial GDPpc $\mathbf{1 9 7 5}$ & 80 & 4.023 & 0.557 & 2.790 & 5.899 \\
Openness & 80 & 16.88 & 7.701 & 2.380 & 44.23 \\
Investments & & & & & \\
\hline
\end{tabular}

Table A3. Descriptive statistics for the entire sample

\begin{tabular}{lccccc}
\hline Variable & Obs & Mean & Std Dev & Min & Max \\
& & & & & \\
\hline & 58 & 1.341 & 2.241 & -5.391 & 5.968 \\
Growth & 58 & 0.137 & 0.107 & 0.010 & 0.543 \\
PrimExp & 58 & 0.046 & 0.078 & 0 & 0.357 \\
OrMetExp & 58 & 0.074 & 0.109 & 0 & 0.509 \\
MinProd & 58 & 0.008 & 0.029 & 0 & 0.198 \\
MidasProd & 58 & 0.530 & 0.135 & 0.232 & 0.872 \\
Institutions & 58 & 7.881 & 0.749 & 6.389 & 9.306 \\
Initial GDPpc $\mathbf{1 9 7 5}$ & 58 & 4.054 & 0.584 & 2.790 & 5.900 \\
Openness & 58 & 14.48 & 7.536 & 2.233 & 44.24 \\
Investments & & & & & \\
\hline
\end{tabular}

Table A4. Descriptive statistics for the developing countries

\begin{tabular}{lccccc}
\hline Variable & Obs & Mean & Std Dev & Min & Max \\
& & & & & \\
\hline & 78 & 0.641 & 7.988 & -10 & 10 \\
Polity75 & 76 & 0.574 & 0.250 & 0.189 & 0.992 \\
Rlaw84 & 76 & 3.237 & 1.789 & 1 & 6 \\
Exprop84 & 76 & 6.137 & 2.150 & 1.8 & 9.8 \\
Repudate84 & 76 & 6.005 & 2.087 & 1.6 & 9.8 \\
Rlaw98 & 80 & 0.230 & 1.013 & -2.153 & 1.996 \\
& & & & & \\
\hline
\end{tabular}

Table A5. Descriptive statistics for other institutional measures 


\section{Appendix B. Dropping and adding control variables}

\begin{tabular}{|c|c|c|c|c|c|}
\hline & (1) & (2) & (3) & (4) & (5) \\
\hline MidasProd & $\begin{array}{l}\mathbf{- 9 5 . 7} * \\
(27.8)\end{array}$ & $\begin{array}{l}\mathbf{- 9 9 . 2 *} \\
(30.4)\end{array}$ & $\begin{array}{l}\mathbf{- 9 6 . 5} * \\
(23.5)\end{array}$ & $\begin{array}{l}\mathbf{- 9 9 . 8 *} \\
(22.4)\end{array}$ & $\begin{array}{l}-\mathbf{1 3 3 . 2} * \\
(28.7)\end{array}$ \\
\hline Institutions & $\begin{array}{l}\mathbf{5 . 5 6 *} \\
(1.36)\end{array}$ & $\begin{array}{l}4.78 * \\
(1.56)\end{array}$ & $\begin{array}{l}\mathbf{6 . 8 6} * \\
(1.25)\end{array}$ & $\begin{array}{l}\mathbf{7 . 1 8 *} \\
(1.31)\end{array}$ & $\begin{array}{l}-0.73 \\
(0.89)\end{array}$ \\
\hline $\begin{array}{l}\text { Interaction } \\
\text { MidasP }{ }^{*} \text { Inst }\end{array}$ & $\begin{array}{l}\text { 167.3* } \\
(38.5)\end{array}$ & $\begin{array}{l}\text { 173.8* } \\
(42.5)\end{array}$ & $\begin{array}{l}169.7 * \\
(32.3)\end{array}$ & $\begin{array}{l}\mathbf{1 7 5 . 0} * \\
(30.7)\end{array}$ & $\begin{array}{l}\text { 221.8* } \\
(41.8)\end{array}$ \\
\hline $\begin{array}{l}\text { Initial GDP } \\
\text { per capita }\end{array}$ & $\begin{array}{l}-\mathbf{2 . 0 2} * \\
(0.29)\end{array}$ & $\begin{array}{l}\mathbf{- 2 . 1 6} * \\
(0.32)\end{array}$ & $\begin{array}{l}\mathbf{- 1 . 9 6 *} \\
(0.30)\end{array}$ & $\begin{array}{l}-\mathbf{2 . 0 0} * \\
(0.32)\end{array}$ & \\
\hline Openness & $\begin{array}{l}0.14 \\
(0.25)\end{array}$ & $\begin{array}{l}0.14 \\
(0.24)\end{array}$ & $\begin{array}{l}0.39 \\
(0.28)\end{array}$ & & \\
\hline Investments & $\begin{array}{l}\mathbf{0 . 0 9 *} \\
(0.03)\end{array}$ & $\begin{array}{l}\mathbf{0 . 0 9 *} \\
(0.03)\end{array}$ & & & \\
\hline Schooling & & $\begin{array}{l}0.12 \\
(0.11)\end{array}$ & & & \\
\hline $\mathrm{R}^{2}$ & 0.70 & 0.71 & 0.66 & 0.65 & 0.49 \\
\hline N. of obs. & 80 & 80 & 80 & 80 & 80 \\
\hline 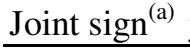 & yes & yes & yes & yes & yes \\
\hline
\end{tabular}

Figures in bold denotes significance at least at the 90 per cent level; at the 99 per cent level. Robust standard errors in parentheses. The dependent variable is growth. All regressions include a constant term and regional dummies for Latin America and Subsaharan Africa not reported). (a): Joint significance is defined as in Table 4.

Table B1. Dropping and adding controls

In Table B1 we add and drop control variables as specified in Section 3. Column (1) redisplays the regression reported in column 4 of Table 4. 
Appendix C. Partial effects of natural resources and institutions
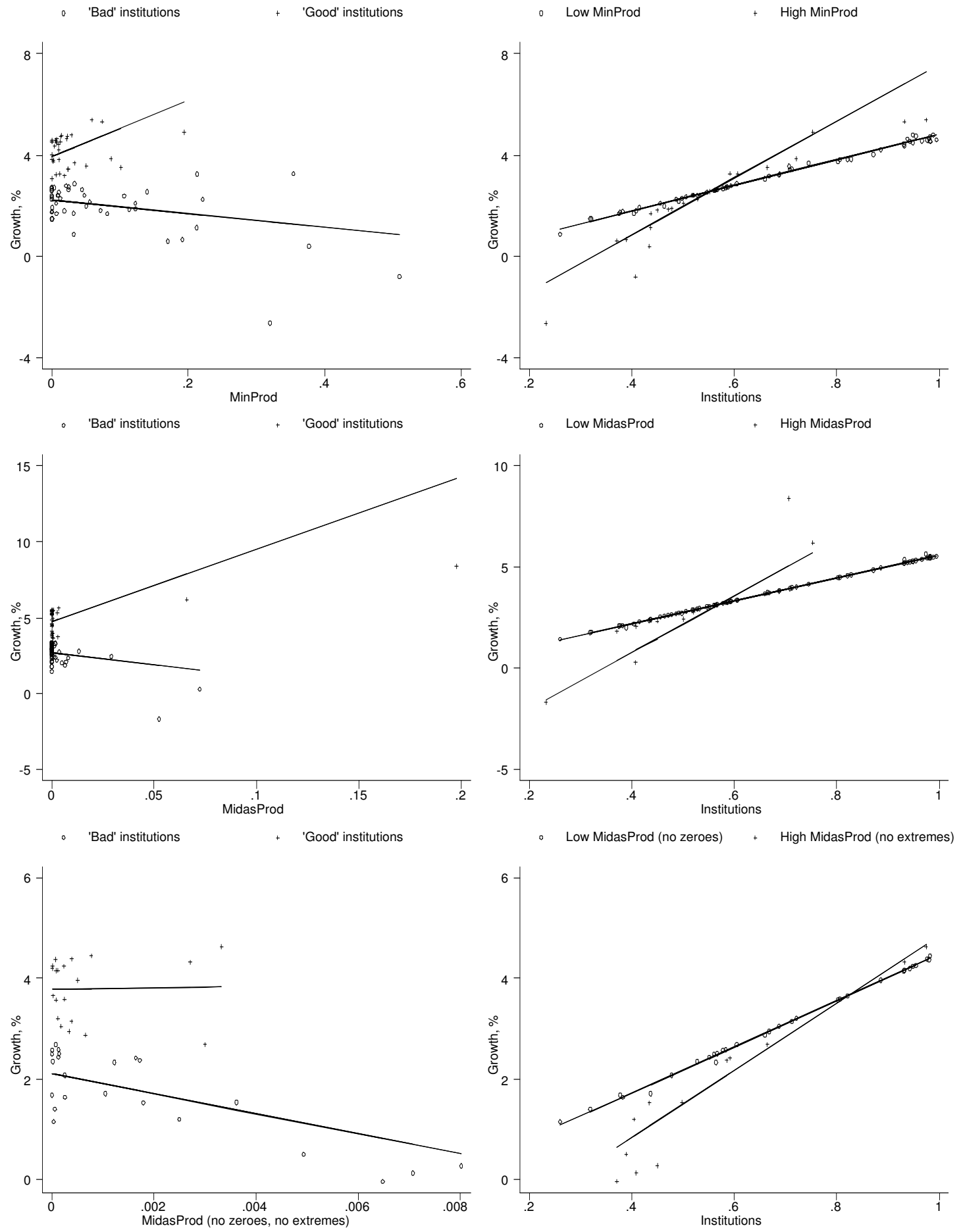

Figures C. Partial effects of natural resources and institutions respectively on growth 
These figures are constructed using coefficient estimates from Table 4, columns (3)-(4), and (not reported) estimates from the regression with MidasProd without extreme observations. (To economise on space we have not reported the corresponding figures using OrMetProd, but they look very similar to MinProd.) The left panel of Figure $\mathrm{C}$ presents the partial effect of natural resources on growth given the quality of institutions. The right part gives the flip side - the effect of institutions on growth given the production of natural resources. They are constructed analogously as described in footnote 21.

The interpretation of all figures to the left is that, regardless of type of natural resource, more of resources are beneficial (detrimental) for growth given that the country has sufficiently good (poor) quality of their institutions. The right part illustrates that improvements of institutional quality are always worthwhile. However, countries with more resources need better institutions in order to have the same growth effect as countries with fewer resources.

Above the institutional threshold level, the partial contribution on growth of resources is higher for a country with plenty of resources than for a country with little resources. Below the institutional cutoff the effect is reversed. Also, considering our technically appropriability hypothesis, the institutional threshold level increases in the technical appropriability of the resource. More specifically, for OrMetProd the institutional cutoff is 0.51, for MinProd 0.55, for MidasProd 0.57, and for MidasProd excluding extremes it is 0.82 . 


\section{Appendix D. First stage regressions when instrumenting} institutions with latitude

\begin{tabular}{|c|c|c|c|c|c|c|c|}
\hline & $\begin{array}{l}(\mathbf{1 A}) \\
\text { Prim } \\
\text { Exp }\end{array}$ & $\begin{array}{l}(\mathbf{1 B}) \\
\text { Prim } \\
\text { Exp }\end{array}$ & $\begin{array}{l}(\mathbf{2 A}) \\
\text { OrMet } \\
\text { Exp }\end{array}$ & $\begin{array}{l}(\mathbf{2 B}) \\
\text { OrMet } \\
\text { Exp }\end{array}$ & $\begin{array}{l}(\mathbf{3 A})(\mathbf{3 B}) \\
\text { Min Min } \\
\text { Prod Prod }\end{array}$ & $\begin{array}{l}(\mathbf{4 A}) \\
\text { Midas } \\
\text { Prod }\end{array}$ & $\begin{array}{l}(\mathbf{4 B}) \\
\text { Midas } \\
\text { Prod }\end{array}$ \\
\hline Resources & $\begin{array}{l}0.02 \\
(0.16)\end{array}$ & $\begin{array}{l}\mathbf{0 . 4 2} * \\
(8.59)\end{array}$ & $\begin{array}{l}\mathbf{- 0 . 5 3} \\
(0.26)\end{array}$ & $\begin{array}{l}\mathbf{0 . 3 1} * \\
(0.02)\end{array}$ & $\begin{array}{l}-0.22 \mathbf{0 . 3 5} * \\
(0.16)(0.02)\end{array}$ & $\begin{array}{l}\mathbf{- 2 . 0 8} \\
(1.21)\end{array}$ & $\begin{array}{l}\mathbf{0 . 2 7} * \\
(0.01)\end{array}$ \\
\hline Latitude & $\begin{array}{l}\mathbf{0 . 2 0} \\
(0.11)\end{array}$ & $\begin{array}{l}\mathbf{- 0 . 0 7 *} \\
(1.64)\end{array}$ & $\begin{array}{l}0.12 \\
(0.10)\end{array}$ & $\begin{array}{l}\mathbf{- 0 . 0 2} \\
(0.01)\end{array}$ & $\begin{array}{ll}\mathbf{0 . 1 6} & \mathbf{- 0 . 0 3} * \\
(0.09) & (0.01)\end{array}$ & $\begin{array}{l}\mathbf{0 . 1 8} \\
(0.08)\end{array}$ & $\begin{array}{l}-0.00 \\
(0.00)\end{array}$ \\
\hline $\begin{array}{l}\text { Interaction } \\
\text { Res } * \text { Lat }\end{array}$ & $\begin{array}{l}-0.01 \\
(0.57)\end{array}$ & $\begin{array}{l}\mathbf{0 . 7 8 *} \\
(18.6)\end{array}$ & $\begin{array}{l}\mathbf{2 . 2 2} \\
(1.23)\end{array}$ & $\begin{array}{l}\mathbf{0 . 9 7 *} \\
(0.10)\end{array}$ & $\begin{array}{l}-0.61 \\
(0.89)(0.12)\end{array}$ & $\begin{array}{l}\mathbf{8 . 9 2} \\
(5.05)\end{array}$ & $\begin{array}{l}\text { 1.75* } \\
(0.05)\end{array}$ \\
\hline $\begin{array}{l}\text { Initial GDP } \\
\text { per capita }\end{array}$ & $\begin{array}{l}\mathbf{0 . 1 4} * \\
(0.02)\end{array}$ & $\begin{array}{l}\mathbf{0 . 0 1} * \\
(0.00)\end{array}$ & $\begin{array}{l}\mathbf{0 . 1 4} * \\
(0.02)\end{array}$ & $\begin{array}{l}\mathbf{0 . 0 0 2} \\
(0.001)\end{array}$ & $\begin{array}{l}\mathbf{0 . 1 5} * \mathbf{0 . 0 1} * \\
(0.02)(0.00)\end{array}$ & $\begin{array}{l}\mathbf{0 . 1 4} * \\
(0.02)\end{array}$ & $\begin{array}{l}-0.00 \\
(0.00)\end{array}$ \\
\hline Openness & $\begin{array}{l}0.01 \\
(0.02)\end{array}$ & $\begin{array}{l}0.00 \\
(0.00)\end{array}$ & $\begin{array}{l}0.02 \\
(0.02)\end{array}$ & $\begin{array}{l}0.00 \\
(0.01)\end{array}$ & $\begin{array}{ll}0.01 & 0.00 \\
(0.02) & (0.00)\end{array}$ & $\begin{array}{l}0.01 \\
(0.02)\end{array}$ & $\begin{array}{l}0.00 \\
(0.00)\end{array}$ \\
\hline Investments & $\begin{array}{l}\mathbf{0 . 0 1} * \\
(0.00)\end{array}$ & $\begin{array}{l}0.00 \\
(0.00)\end{array}$ & $\begin{array}{l}\text { 0.01* } \\
(0.00)\end{array}$ & $\begin{array}{l}\mathbf{0 . 0 0 0 3} \\
(0.0002)\end{array}$ & $\begin{array}{ll}\mathbf{0 . 0 1} & -0.00 \\
(0.00) & (0.00)\end{array}$ & $\begin{array}{l}\text { 0.01* } \\
(0.00)\end{array}$ & $\begin{array}{l}0.00 \\
(0.00)\end{array}$ \\
\hline $\begin{array}{l}\mathrm{R}^{2} \\
\mathrm{~N} \text {. of obs. }\end{array}$ & $\begin{array}{l}0.86 \\
80 \\
\end{array}$ & $\begin{array}{l}0.91 \\
80 \\
\end{array}$ & $\begin{array}{l}0.85 \\
80\end{array}$ & $\begin{array}{l}0.97 \\
80 \\
\end{array}$ & $\begin{array}{ll}0.86 & 0.94 \\
80 & 80 \\
\end{array}$ & $\begin{array}{l}0.85 \\
80\end{array}$ & $\begin{array}{l}0.99 \\
80\end{array}$ \\
\hline \multicolumn{8}{|c|}{ Significance of instruments $^{(\mathrm{a})}$} \\
\hline $\begin{array}{l}\mathrm{F}(2,71) \\
\mathrm{P} \text {-value }\end{array}$ & $\begin{array}{l}2.77 \\
0.07 \\
\end{array}$ & $\begin{array}{l}22.8 \\
0.00\end{array}$ & $\begin{array}{l}4.89 \\
0.01\end{array}$ & $\begin{array}{l}59.9 \\
0.00 \\
\end{array}$ & $\begin{array}{ll}1.74 & 21.3 \\
0.18 & 0.00 \\
\end{array}$ & $\begin{array}{l}4.46 \\
0.02 \\
\end{array}$ & $\begin{array}{l}637 \\
0.00\end{array}$ \\
\hline
\end{tabular}

Figures in bold denotes significance at least at the 90 per cent level; * at the 99 per cent level. Robust standard errors in parentheses. The dependent variable is institutions in columns A, and the interaction term of institutions and natural resources in columns B. All regressions include a constant term and regional dummies for Latin America and Subsaharan Africa (not reported). (a): Significance of the instruments reports the joint significance of excluded instruments.

Table D1. First stage regressions when instrumenting institutions with latitude 


\section{Appendix E. Some results when using FuelOrMetExp}

\begin{tabular}{|c|c|c|c|c|}
\hline & $\begin{array}{l}(1-\mathrm{LS}) \\
\text { Main } \\
\text { regression }\end{array}$ & $\begin{array}{l}\text { (2-2SLS) } \\
\text { Instrument: } \\
\text { latitude }\end{array}$ & $\begin{array}{l}\text { (3-LS) } \\
\text { Developing } \\
\text { countries }\end{array}$ & $\begin{array}{l}\text { (4-LS) } \\
\text { Without } \\
\text { controls }\end{array}$ \\
\hline $\begin{array}{l}\text { FuelOrMet } \\
\text { Exp }\end{array}$ & $\begin{array}{l}-4.76 \\
(3.86)\end{array}$ & $\begin{array}{l}2.04 \\
(21.1)\end{array}$ & $\begin{array}{l}-3.59 \\
(4.72)\end{array}$ & $\begin{array}{l}\mathbf{- 1 2 . 8 *} \\
(3.96)\end{array}$ \\
\hline Institutions & $\begin{array}{l}\text { 6.63* } \\
(2.26)\end{array}$ & $\begin{array}{l}\mathbf{1 5 . 6} \\
(8.29)\end{array}$ & $\begin{array}{l}9.21 * \\
(3.13)\end{array}$ & $\begin{array}{l}0.85 \\
(1.15)\end{array}$ \\
\hline $\begin{array}{l}\text { Interaction } \\
\text { FuelOr*Inst }\end{array}$ & $\begin{array}{l}8.19 \\
(6.25)\end{array}$ & $\begin{array}{l}0.68 \\
(37.5)\end{array}$ & $\begin{array}{l}6.10 \\
(7.71)\end{array}$ & $\begin{array}{l}\mathbf{2 2 . 5} \text { * } \\
(5.81)\end{array}$ \\
\hline $\begin{array}{l}\text { Initial GDP } \\
\text { per capita }\end{array}$ & $\begin{array}{l}\mathbf{- 2 . 1 4} * \\
(0.42)\end{array}$ & $\begin{array}{l}\mathbf{- 3 . 5 7} \\
(1.43)\end{array}$ & $\begin{array}{l}-\mathbf{1 . 9 6 *} \\
(0.44)\end{array}$ & \\
\hline Openness & $\begin{array}{l}\mathbf{0 . 1 8} \\
(0.31)\end{array}$ & $\begin{array}{l}-0.03 \\
(0.63)\end{array}$ & $\begin{array}{l}0.15 \\
(0.36)\end{array}$ & \\
\hline Investments & $\begin{array}{l}\mathbf{0 . 0 9} * \\
(0.03)\end{array}$ & $\begin{array}{l}0.04 \\
(0.08)\end{array}$ & $\begin{array}{l}0.06 * \\
(0.04)\end{array}$ & \\
\hline $\begin{array}{l}\mathrm{R}^{2} \\
\mathrm{~N} \text {. of obs. }\end{array}$ & $\begin{array}{l}0.60 \\
80\end{array}$ & $\begin{array}{l}0.68 \\
80\end{array}$ & $\begin{array}{l}0.63 \\
58\end{array}$ & $\begin{array}{l}0.39 \\
80\end{array}$ \\
\hline
\end{tabular}

Figures in bold denotes significance at least at the 90 per cent level; * at the 99 per cent level. Robust standard errors in parentheses. The dependent variable is growth. All regressions include a constant term and regional dummies for Latin America and Subsaharan Africa (not reported).

Table E1. Regression results for FuelOrMetExp 